بررسى برخى صفات رشدى و عملكردى گياه كاملينا (Camelina sativa L) تحت تأثير كودهاى زيستى و شيميايى

مرضيه حسنى بليانى'، محمودرضا تدين "و علىاكبر فدايى تهرانى

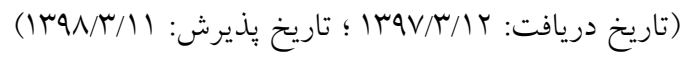

جكيده

كاملينا (Camelina sativa L.

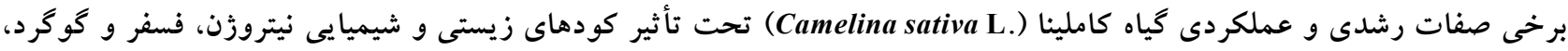

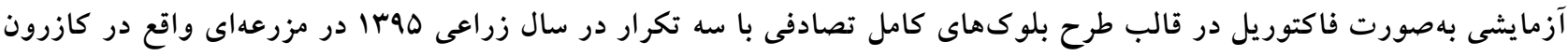

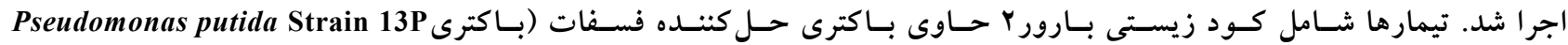

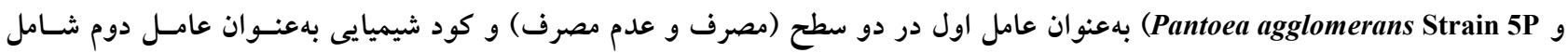

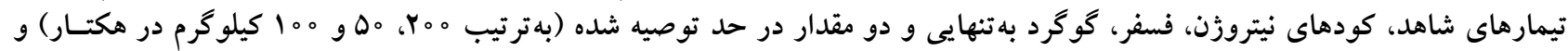

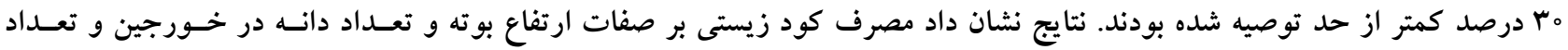

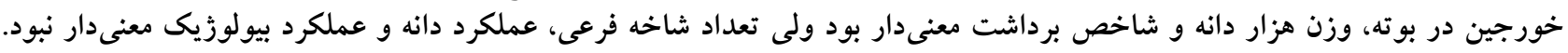

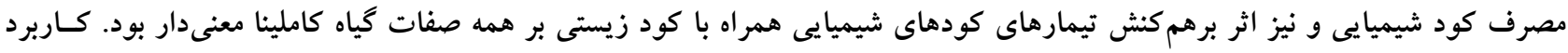

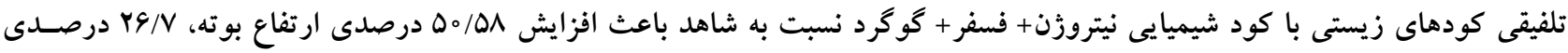

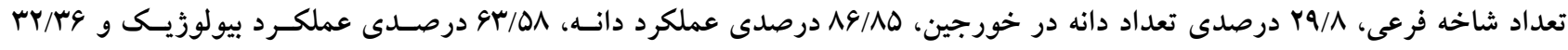

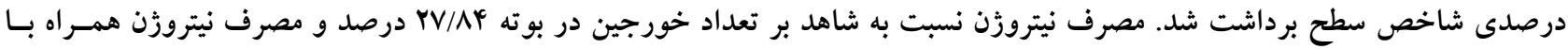

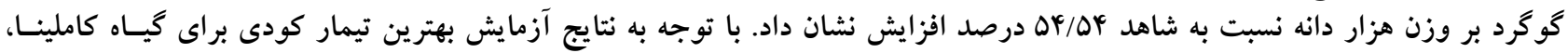

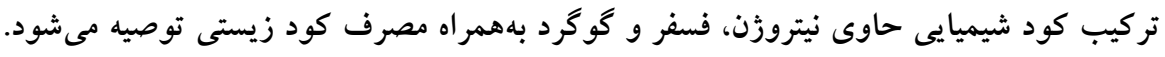

وازههاى كليدى: تعداد دانه، تعداد خورجين، شاخص برداشت، عملكرد بيولوزيك، وزن هزار دانه

ا و r. بهترتيب دانشجوى كارشناسى ارشد و دانشيار، كروه زراعت، دانشكده كشاورزى، دانشخاه شهركرد

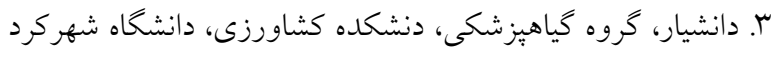

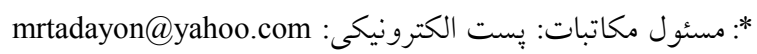


از فرم غير قابل دسترس به فرم قابـل دسترس طلى فراينـدهاى

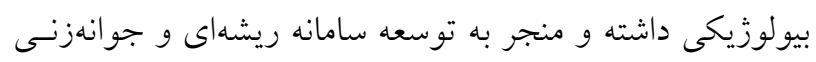

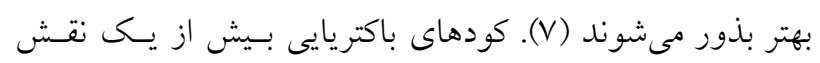

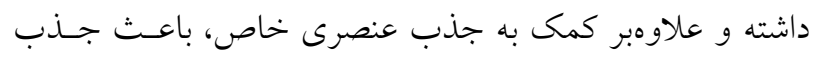

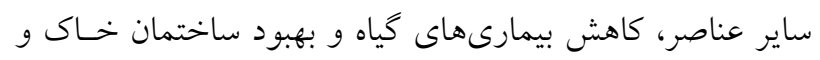

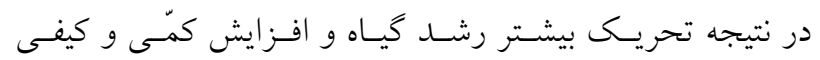

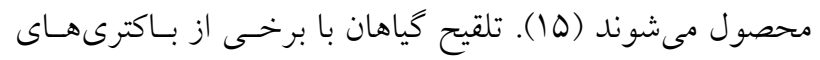

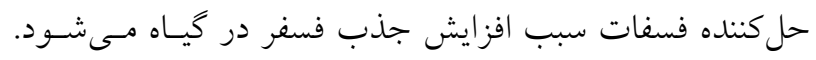

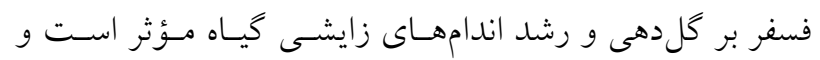

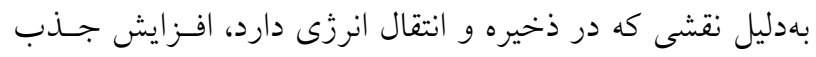

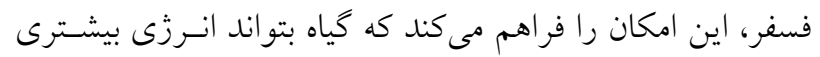

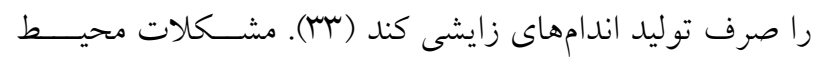

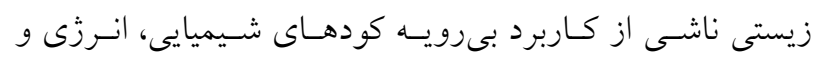

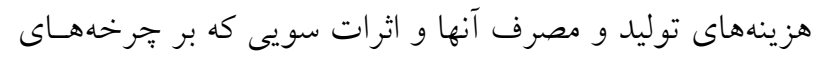

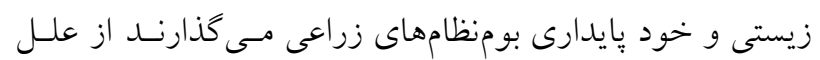

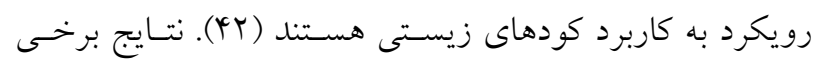

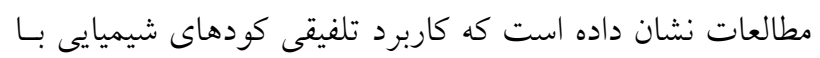

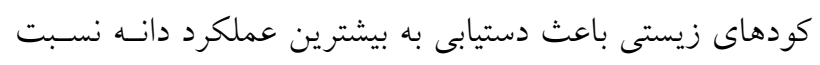

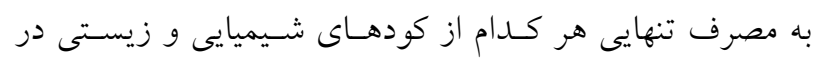
كياهان مىشود (†). بررسى مطالعات انجـام شــده روى كـاربرد

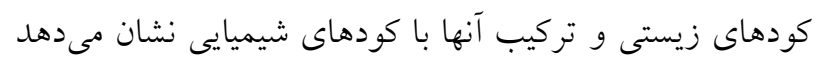

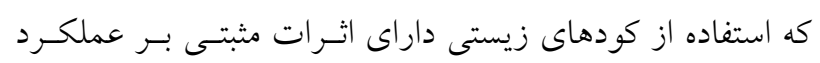

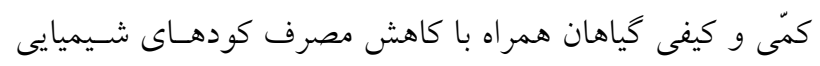

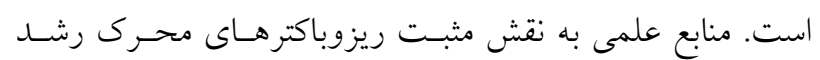

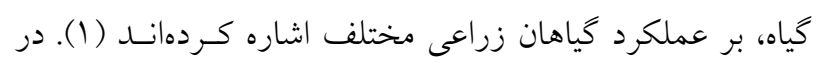

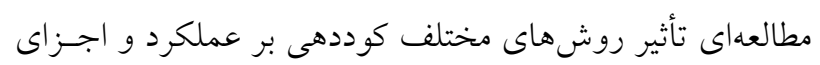

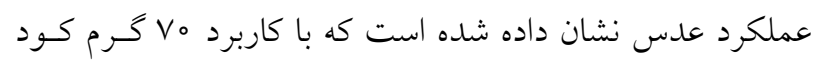

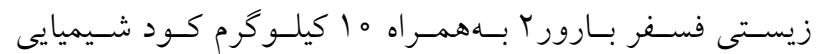

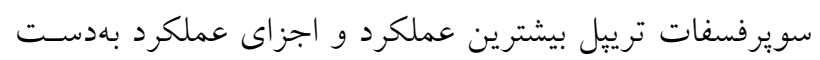

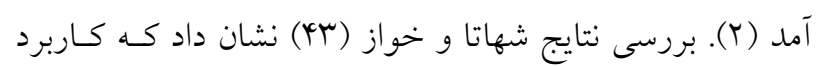
كود زيستى شامل باكترىهاى افزاينده رشد، عملكرد آفتـابحردان

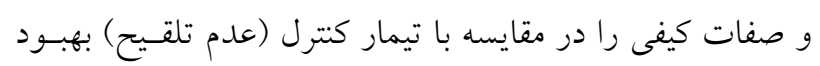

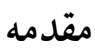

كاملينا (Camelina sativa L.) كياهى روغنى يكساله متعلق بـه خانواده براسيكاسه (Brassicaceae) و بومى شمال ارويـا اسـت

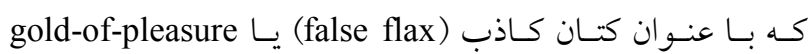
شناخته شده است. جرخه زندگى ايسن گيـاه كوتـاه (هم تـاهـا روز) با سامانه ريشهاى كمعمق است. ساز گارى خوبى با منـاطق

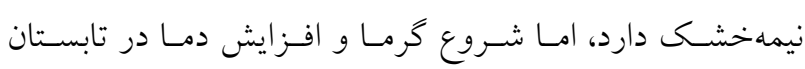
مى تواند عملكرد دانه را تحت تأثير قرار دهـــ (آا). در شـرايط آبوهو ائى مختلف و انواع وضعيت خاكى بـهـعنـوان يــ كيـاه بهاره يا تابستانه يكساله يا بهعنوان يك گيـاه زمسـتانه دوسـاله

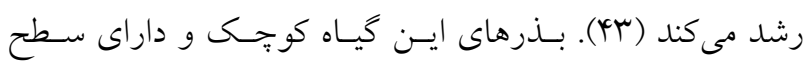

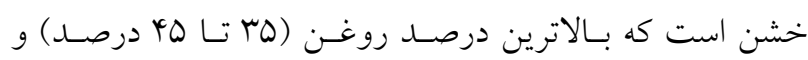
بيشترين كارايى مصرف آب در مقايسه با ديخر دانههاى روغنى

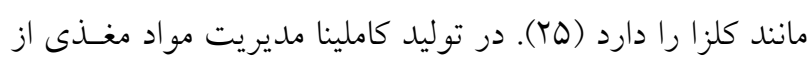
عوامل مهمى است كه بر رشــ، عملكــرد و كيفيـت دانـه تـأثير

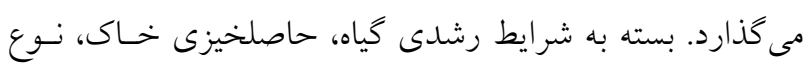

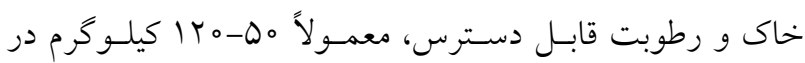

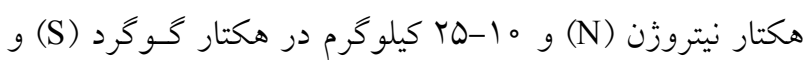
ها تا هب كيلو گرم در هكتار فسفر (P) براى توليــ كاملينـا نيـاز

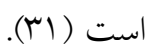
نيتروزن جهارمين عنصر اصلى تشـكيلدهنـده وزن خشكى

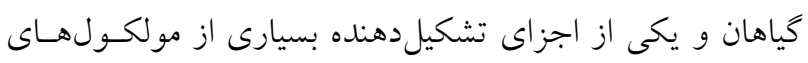
مهم از قبيل بروتئينها، اسيدهاى نوكلئيك، برخسى هورمـونهـا، كلروفيل و انواع ديخرى از مواد سازنده اوليـه و ثانويـه كياهـان است (1)). نيتروزن و بعد از آن فسفر مهمترين عناصرى هستند

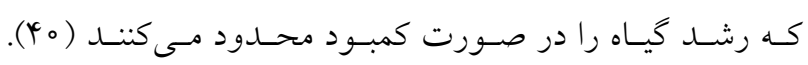

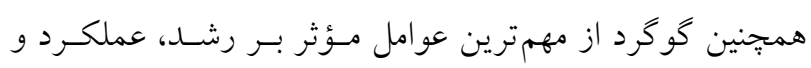
كيفيت محصول در گياهان دانه روغنسى محسـوب مسى شـود، از اينرو يزوهشخران كشاورزى توصيه مى كنند كـهـ بـــاى كياهـان روغنى كو گرد را نيز به NPK اضافه كنند (r).

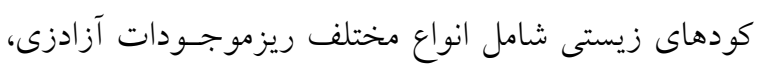
مانند باكترىها هستند كه توانايى تبديل عناصر غذايى اصسلى را 


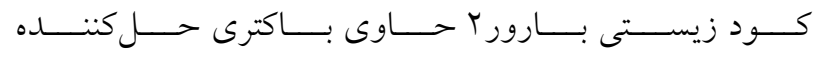

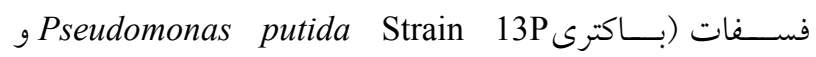
(Pantoea agglomerans Strain 5P

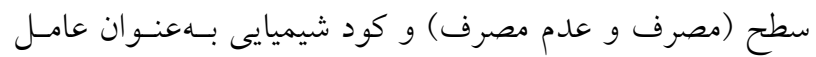
دوم شامل تيمارهاى شاهد، كودهـاى نيتـروزن، فسـفر، گــوكرد

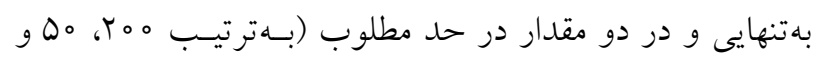

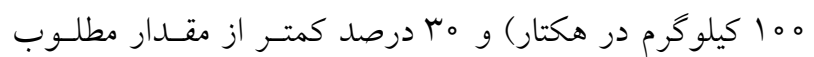

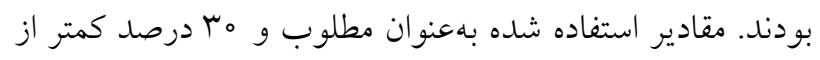
مطلوب در تيمار كود شيميايى بر اساس آزمون خـاك و توصسيه

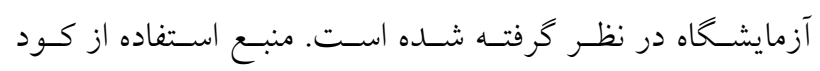

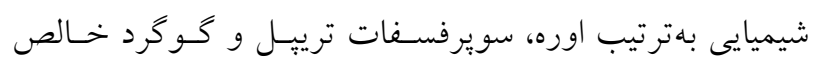

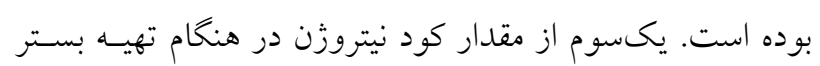

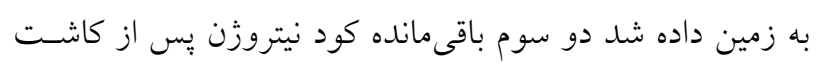

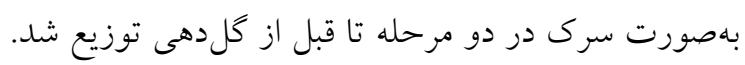

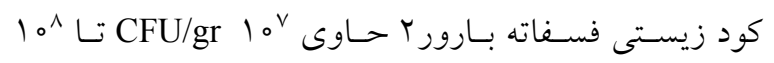

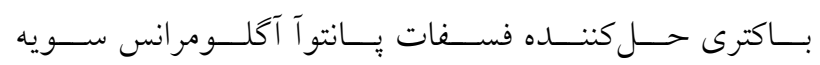
(Pantoea agglomerans Strain 5P) P5 سويه (Pseudomonas putida Strain 13P) P13 در هر خرم از كود است كه با توليد اسيدهاى اركانيك و آنزيمهاى فسفاتاز در

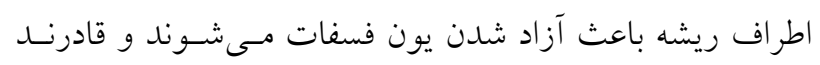

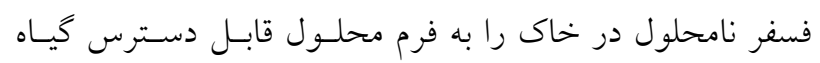

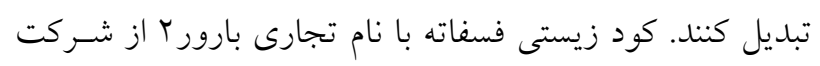
زيستفناور سبز تهيه شد.

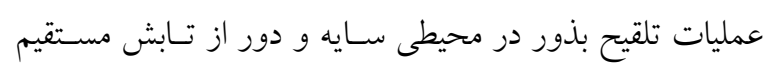

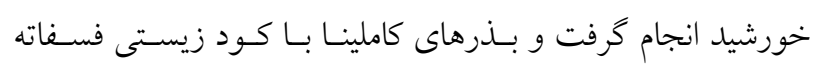

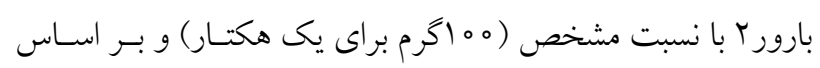

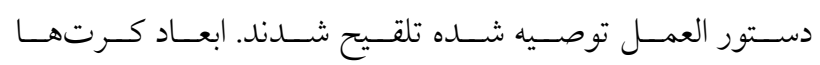

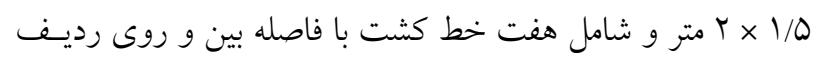

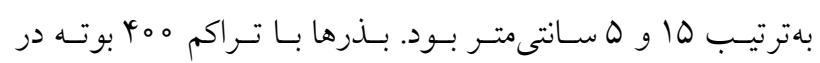

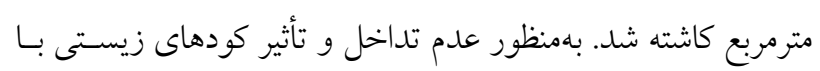

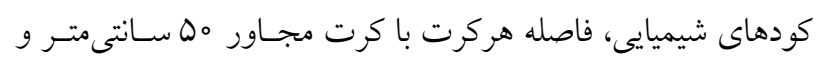

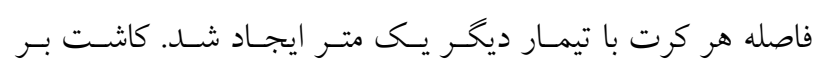

بخشيدند بهطورى كه سبب افزايش عملكرد دانه، ميزان روغن و

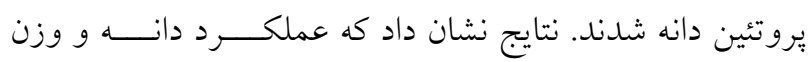

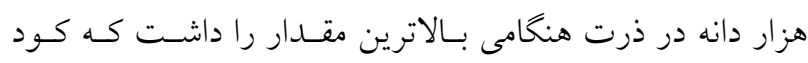

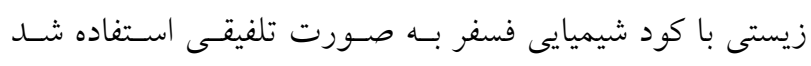

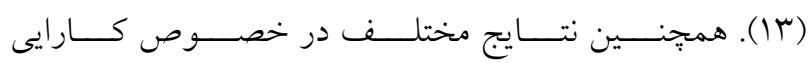

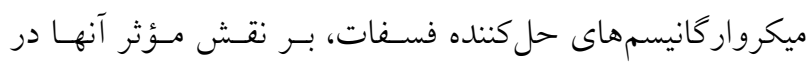

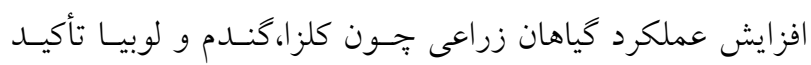

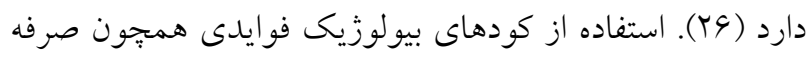

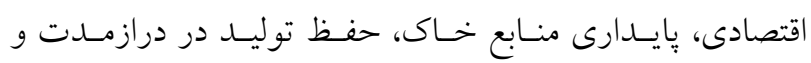

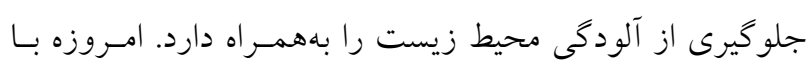

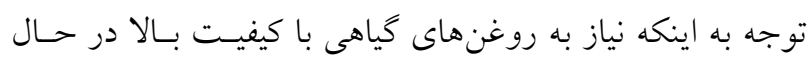

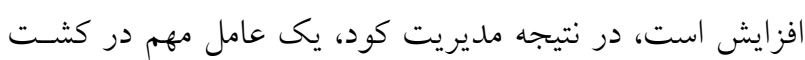

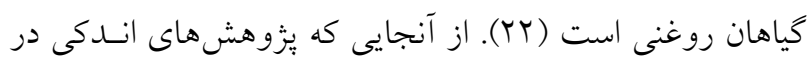

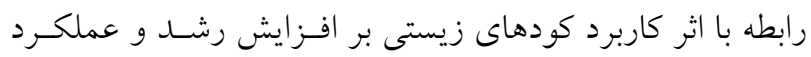

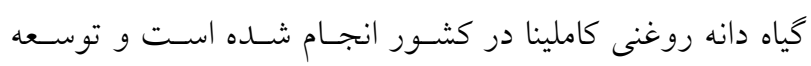

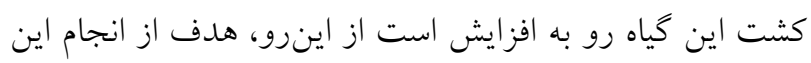
آزمايش، بررسى برخى صفات رشدى و عملكردى گياه كاملينـا

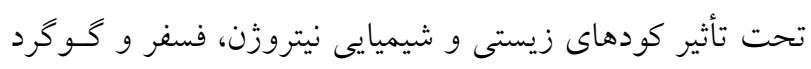

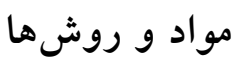

اين آزمايش در مزرعهاى با مختصات طول جغرافيايى له دورجه

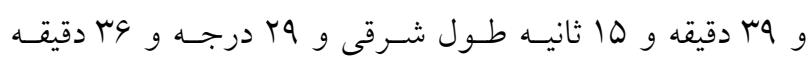

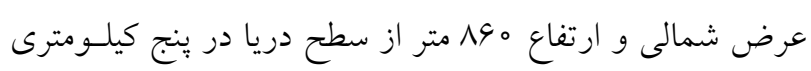

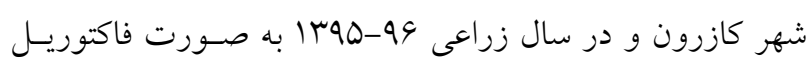
در قالب طرح بلوكهاى كامل تصادفى در سه تكرار اجرا شد.

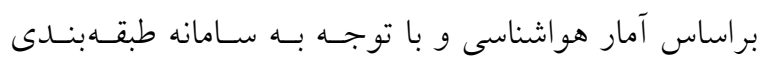

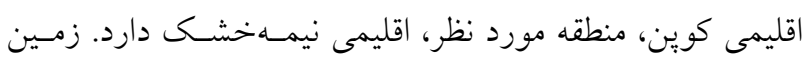
محل آزمايش در سال قبل از كشت، كُندم بوده است. بـهمنظـور

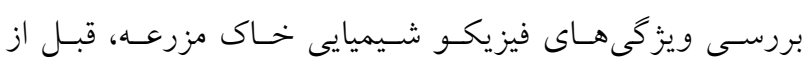

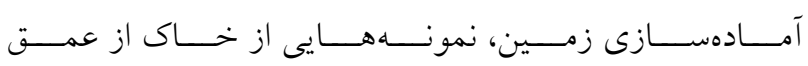

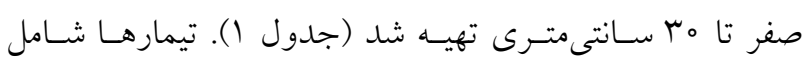


جدول ا. مشخصات فيزيكى و شيميايى خاك مزرعه قبل از اعمال تيمارها

\begin{tabular}{|c|c|c|c|c|c|c|c|}
\hline $\begin{array}{c}\text { روى } \\
(\mathrm{mg} / \mathrm{kg})\end{array}$ & $\begin{array}{c}\text { آهن } \\
(\mathrm{mg} / \mathrm{kg})\end{array}$ & $\begin{array}{c}\text { نيتروزن } \\
\text { (\%) }\end{array}$ & $\begin{array}{c}\text { يتاسيم قابل جذب } \quad \text { (mg/kg) }\end{array}$ & فسفرقابل جذب & درصد اشباع & $\begin{array}{l}\text { شورى } \\
(\mathrm{dS} / \mathrm{m})\end{array}$ & اسيديته \\
\hline $1 / \mu$ & r & $0 / 14$ & IVY & $r / q$ & 49 & $0 / 9$ & $V / q$ \\
\hline بافت خاك & $\begin{array}{l}\text { آهك } \\
(\%)\end{array}$ & $\begin{array}{l}\text { رس) } \\
(\%)\end{array}$ & ل & شن & كربن آلى & $\begin{array}{c}\text { منزخنز } \\
(\mathrm{mg} / \mathrm{kg})\end{array}$ & $\begin{array}{c}\text { مس } \\
(\mathrm{mg} / \mathrm{kg})\end{array}$ \\
\hline لوم رسى سيلتى & $10 / 0$ & $r V / r$ & ty & $1 N / 1$ & $1 / 40$ & V/TY & $\circ / N G$ \\
\hline
\end{tabular}

جدول r. درجه آزادى و ميانخين مربعات برخى ويزّگىهاى مربوط به رشد و اجزاى عملكرد دانه گياه كاملينا

\begin{tabular}{|c|c|c|c|c|c|}
\hline \multicolumn{4}{|c|}{ ميانخين مربعات } & \multirow{2}{*}{ درجه آزادى } & \multirow{2}{*}{ منبع تغييرات } \\
\hline تعداد دانه در خورجين & تعداد خورجين در شاخه & تعداد شاخه فرعى & ارتفاع بوته & & \\
\hline$T / 4 \varphi^{* *}$ & $1 / r \wedge^{\mathrm{ns}}$ & $1 / \wedge \Delta V^{* *}$ & $\Gamma \times q / T^{* *}$ & $r$ & تكرار \\
\hline$\circ / 4 q^{*}$ & $r \xi \circ / \circ r^{* *}$ & $\circ /$ YGyns & $k q / r \mu^{*}$ & 1 & كودزيستى \\
\hline$T / 99^{* *}$ & $q 4 / 4 q^{* *}$ & 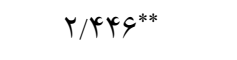 & 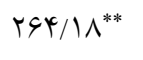 & 10 & كود شيميايى \\
\hline$r / 4 q^{* *}$ & $\mathcal{K} / \mathscr{K} \varphi^{* *}$ & $1 / \Upsilon \wedge \Lambda^{* *}$ & $r \Delta \circ / \circ Q^{* *}$ & 10 & كود زيستى × كود شيميايى \\
\hline.$/ 11$ & $T / M$ & $0 / 0 \wedge 9$ & $11 / 1$ & LY & خطا \\
\hline$r / 9 \Lambda$ & $r / 9 T$ & $Y / r)$ & $4 / 91$ & - & ضريب تغييرات (.٪) \\
\hline
\end{tabular}

كـرت از رديـفـهـاى ميـانى بـس از حسـف اتــرات حاشـيهاى برداشت انجام و عملكرد بيولوزيـك، عملكــــد دانـه و شـاخص برداشت اندازه گيرى شـد. تجزيسه واريـانس و مقايسـه ميـانخين

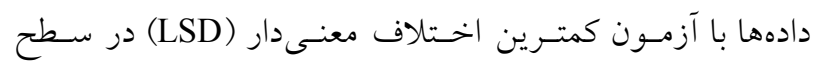

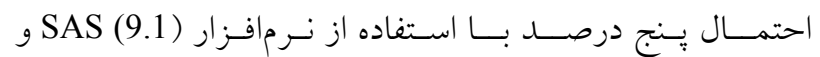
MSTATC و رسـم نمودارهــا بـا نرمافـزار Excel انجام شد.

\section{نتايج و بحث

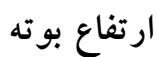
نتايج تجزيه واريانس نشان داد اثر تيمارهـاى كـود شسيميايى در سطح احتمال يكى درصـد و تيمارهـاى كـود زيسـتى در سـطح احتمال ينج درصد بر ارتفاع بوته معنىدار بوده اسـت. همجنــين برهم كنش كود شيميايى و زيستى در سطح احتمال يـك درصـد بر اين صفت معنى دار بود (جدول r). استفاده از تيمارهاى كـود
اساس شرايط آبووهوايى منطقه در بهمنمـاه هوبا انجـام شـد. اولـين مرحلــه آبيـارى مزرعسه بلافاصــله يــس از كاشـت و و آبيارىهاى بعدى براساس شرايط محسل، رطوبـت خــاى و دور مرسوم آبيارى گياه كاملينا انجام گرفت. عمليات برداشت بوتهها با زرد شدن كامل خوشهها بـهمنظـور تعيسين عملكـرد نهـايى و صفات مرتبط بـا عملكـــرد، در اوايـل خردادمـاه وهباصـورت

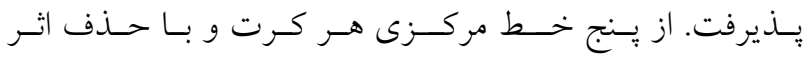
حاشيهاى و با كفبر كردن بوتهها (بــهــور تصــادفى) اقـــدام بـــهـ نمونهبردارى شد. براى اندازهگيرى صفات مورد نظر قبل از

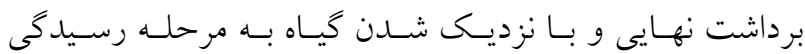
فيزيولوزيك، تعداد ه ا بوته از هر كرت بهطور تصادفى انتخاب و به آزمايشخاه منتقل شد و صفات ارتفــاع بوتـه، تعـداد شـاخه فرعى، تعداد خورجين در بوته، تعداد دانـه در خـورجين و وزن لـون هزار دانه اندازهيرى شدند؛ براى تعيين عملكرد نهـايى، در هـر 


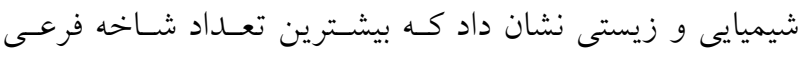

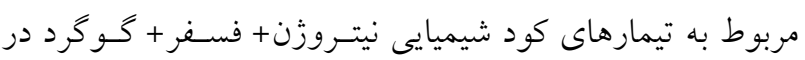

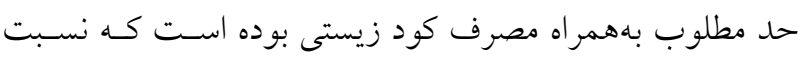

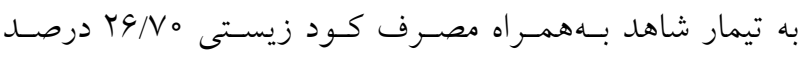

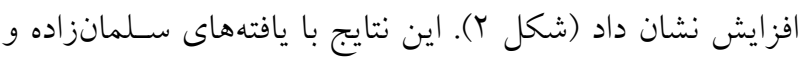
همكاران (4) مطابقت داشت. تعـداد شـاخه فرعى از صـفات

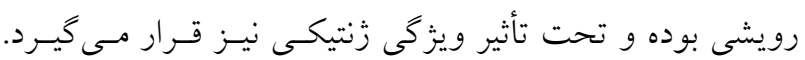

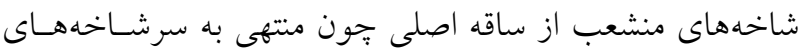

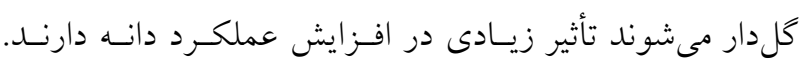

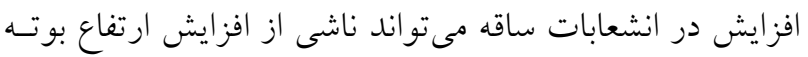

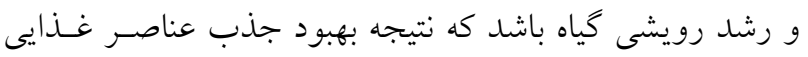

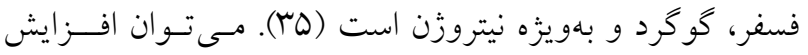
جـــب آب و دسترسى به مـــواد غــذايى كـه عـاملى مـؤثر در توسـعه بيسشتر ريـشههـا، بهبود شرايط براى رشد و توليد مـواد

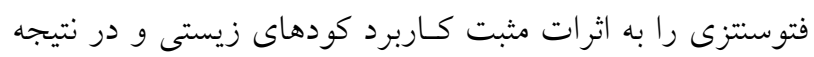

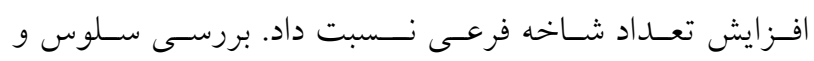

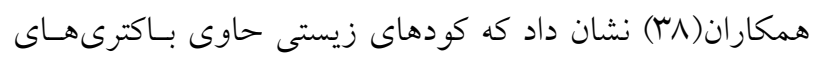

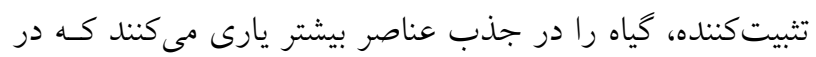

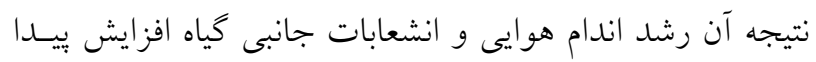

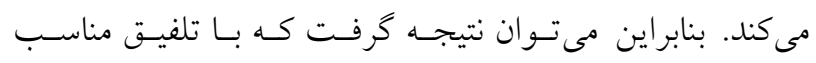

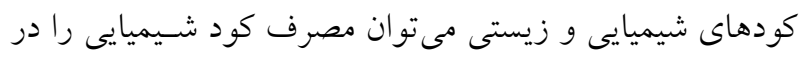
مزارع كاهش داد.

\section{تعداد خورجين در بوته}

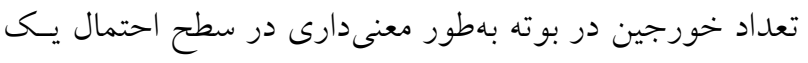

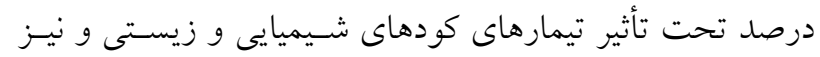
برهم كنش آنها قرار كرفت (جـــول Y). اسـتفاده از تيمـار كـود شيميايى نيتروزن در حد مطلوب، بههمراه مصرف كـود زيستى باعث افزايش TV/AK درصدى تعداد خورجين در بوته نسبت به

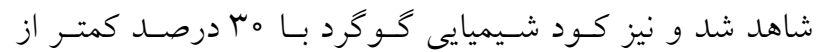

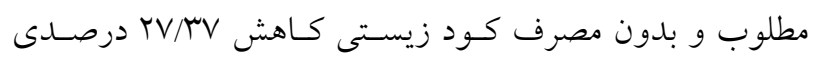

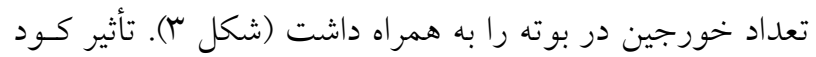

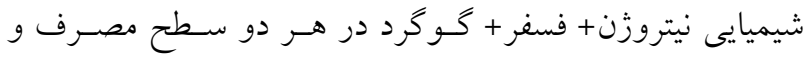

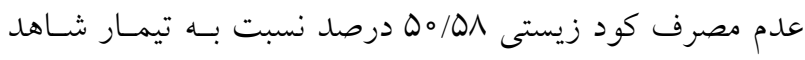
بلدون مصرف كود زيستى افـزايش نشـان داد (شـكل (1). علـت

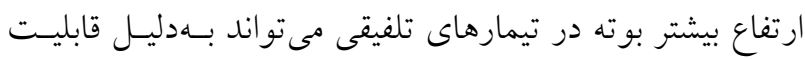

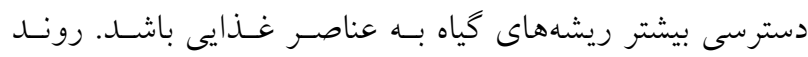

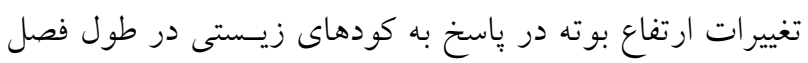

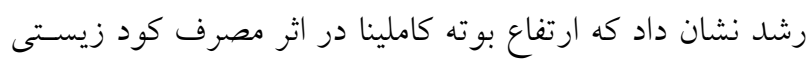

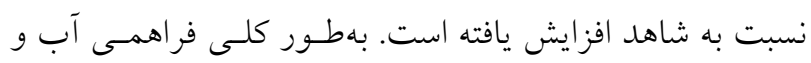

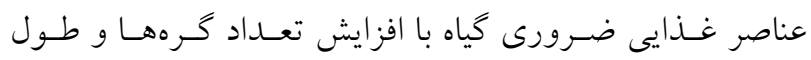

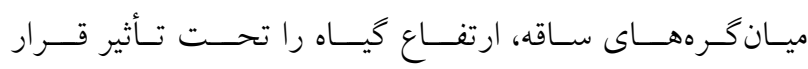

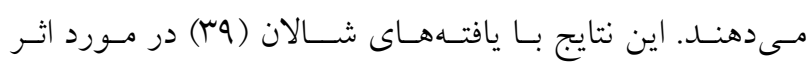

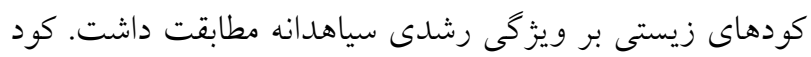

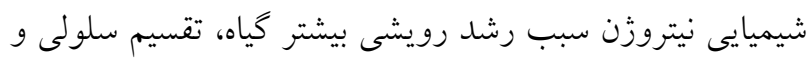

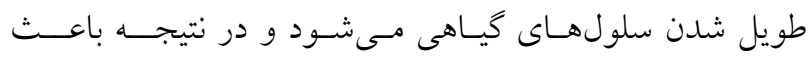

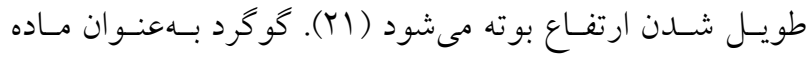

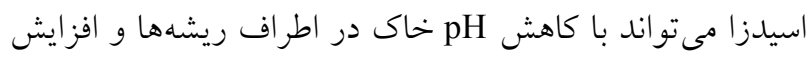

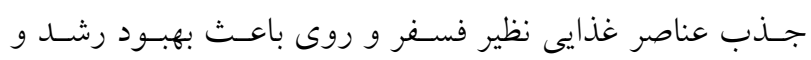

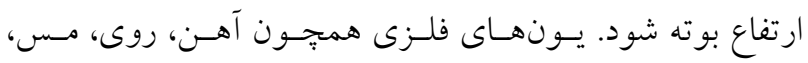

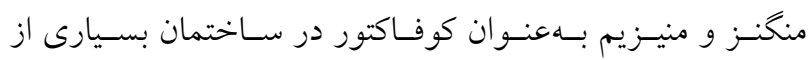
آنزيمهاى آنتى اكسيدانت مشاركت داشته و مئى توانند در افـزايش

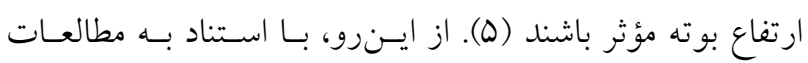

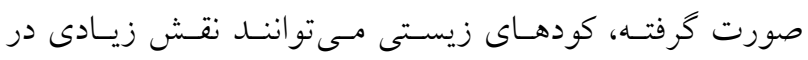

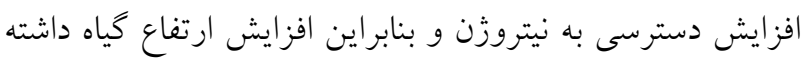
باشند.

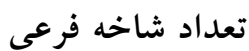

اتخر كودهاى شسيميايى در سطح احتمال يكى درصـد بـر تعـداد شاخه فرعى معنسىدار بود، ولى اثر كود زيستى بـر تعــاد شاخه

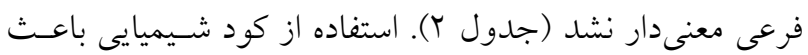

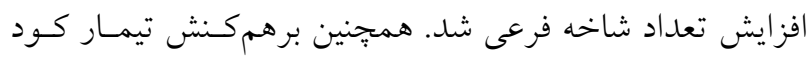
شيميايى و زيستى در سططح احتمال يك درصد بر تعداد شـاخه

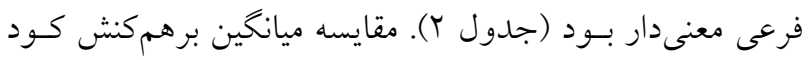




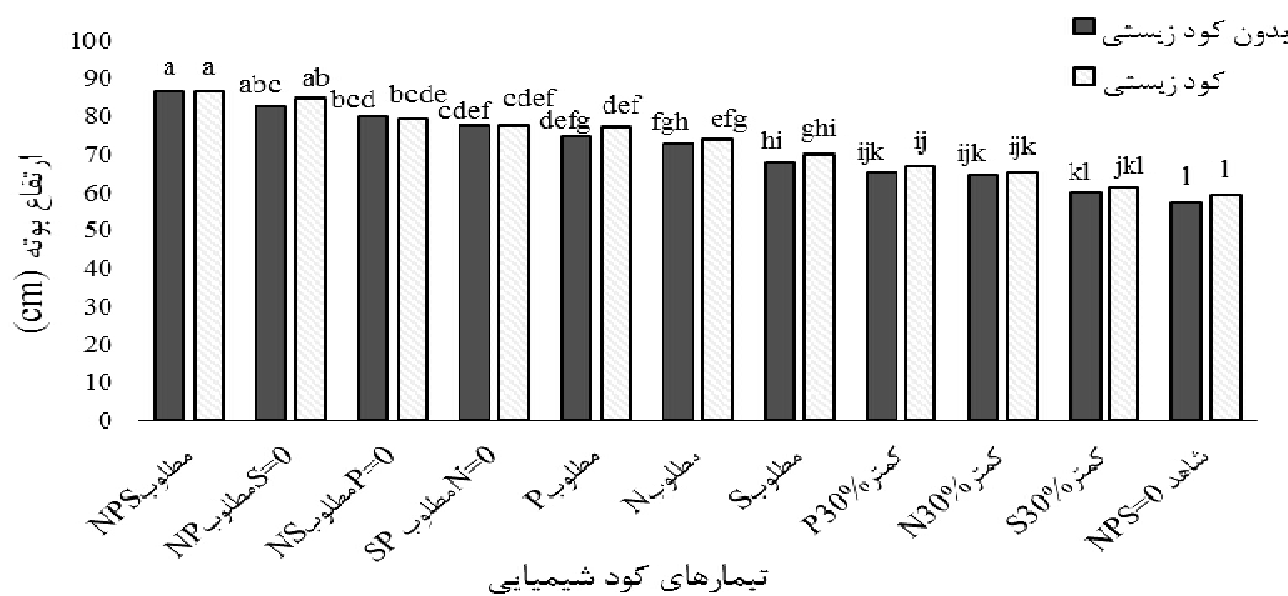

شكل ا. مقايسه ميانكين اثر برهم كنش كود شيميايى × كود زيستى بر ارتفاع بوته كاملينا. ستونهايى كه داراى حروف مشترك هستند

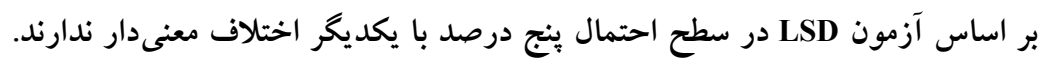

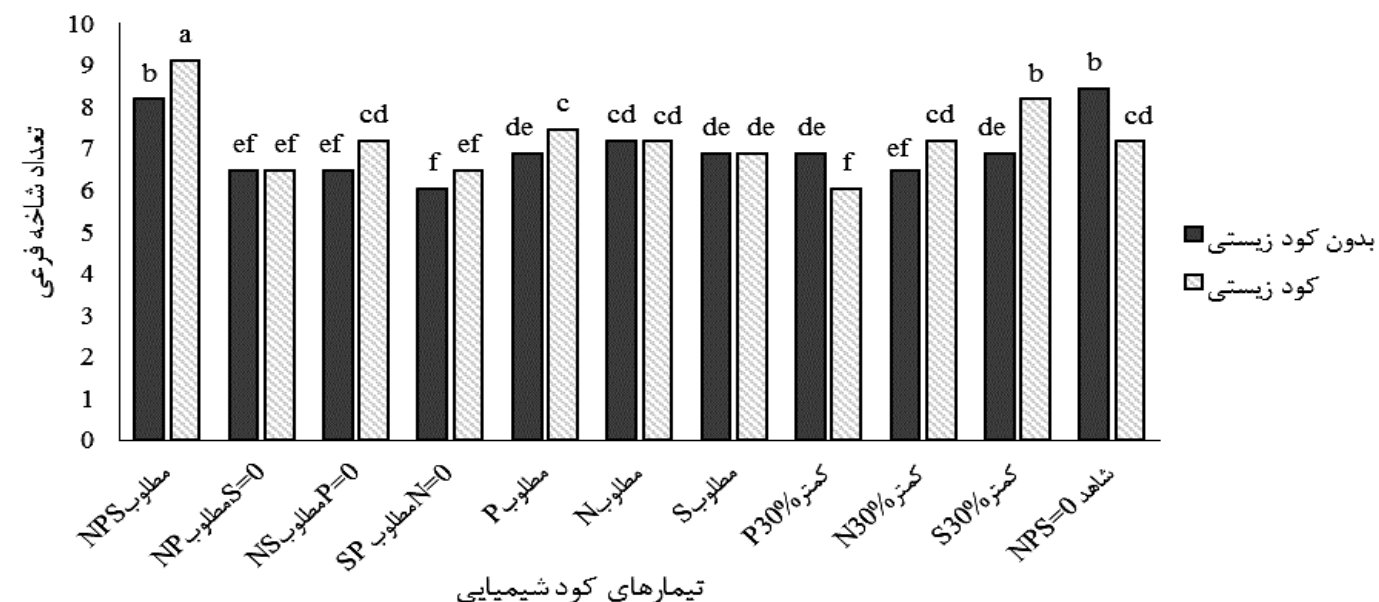

شكل r. مقايسه ميانكين اثر برهم كنش كود شيميايى در كود زيستى بر تعداد شاخه فرعى در بوته در كاملينا. ستوذهايى كه داراى حروف

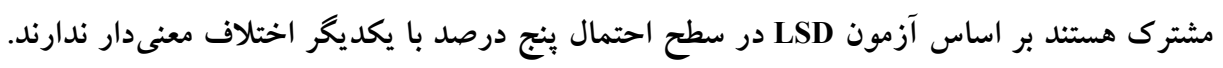

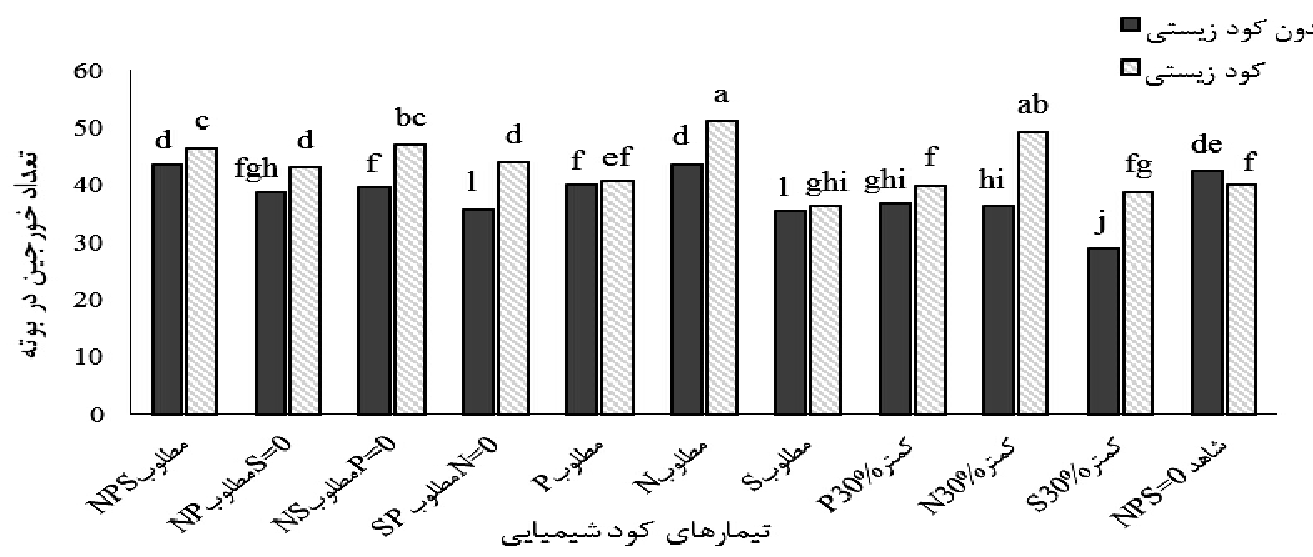

شكل r. مقايسه ميانكين اثر برهم كنش كود شيميايى در كود زيستى بر تعداد خورجين در بوته كاملينا. ستونهايى كه داراى حروف مشترى

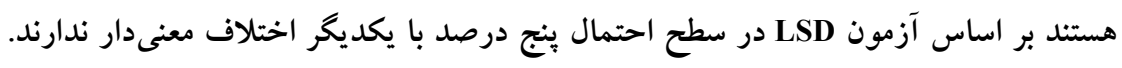


افزايش تعـداد دانـه مسى شـود (IV). در آزمايشسى مزرعسهاى بـا

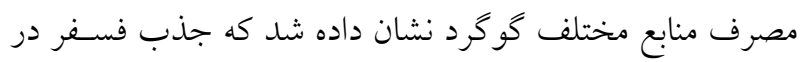

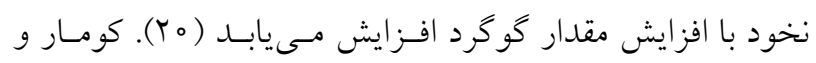

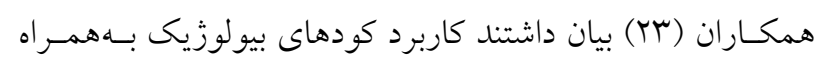

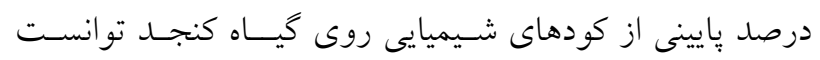

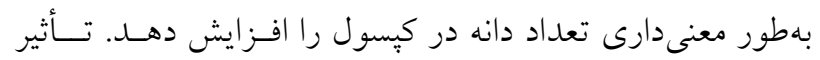

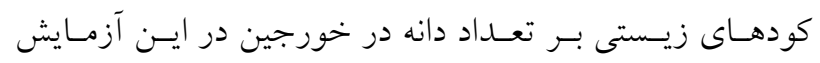

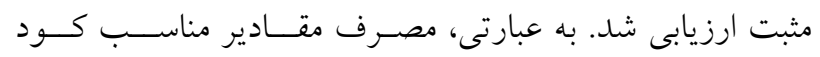

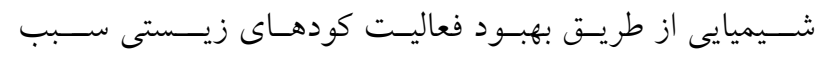

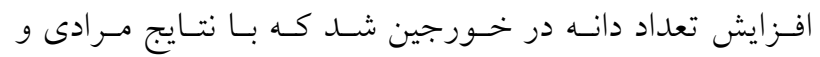
همكاران (YN) مطابقت داشت.

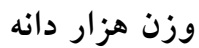

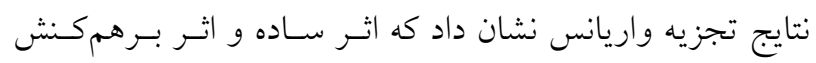
كودهاى شيميايى و زيستى بر وزن هزار دانه در سـطح احتمـال

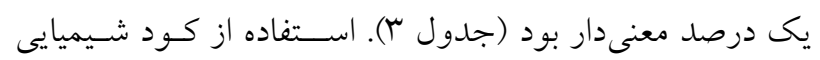

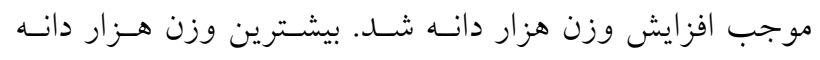

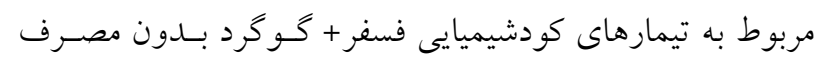

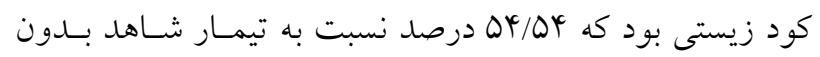
مصرف كود زيستى افزايش نشـان داد (شـكل ه) كـه بـا نتسايج

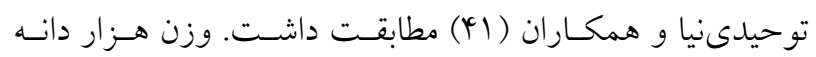

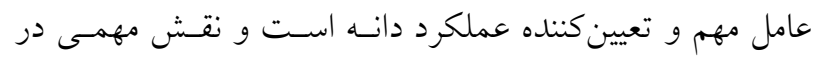

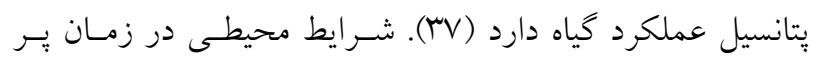

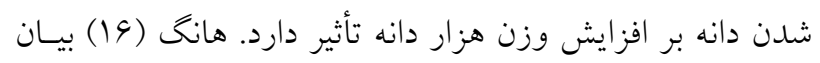

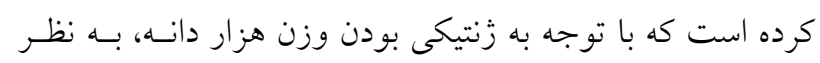

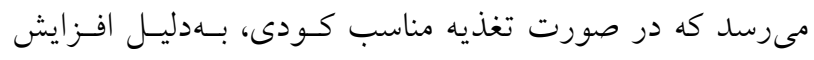

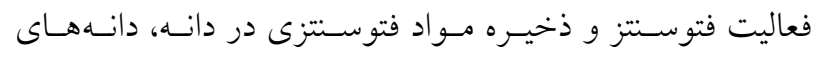

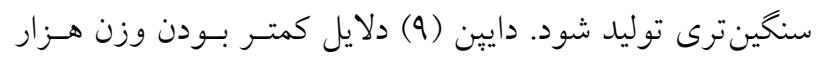

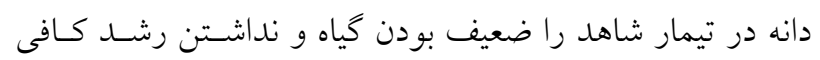
براى ساخت و انتقال مو اد غذايى به دانهها بيان مى كند. همديجنين

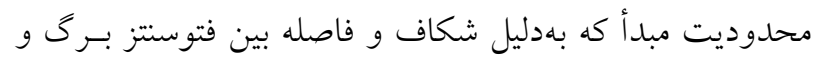

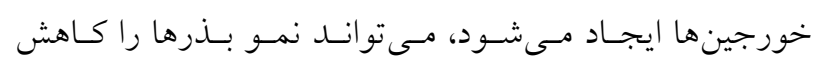

زيستى بر تعداد خورجين در بوته در اين آزمايش مثبت ارزيابى

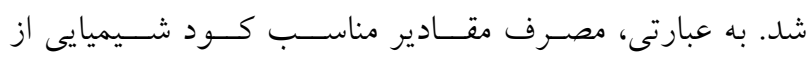
طريق بهبود فعاليت كودهاى زيسـستى، ســبب افــز ايش تعسداد

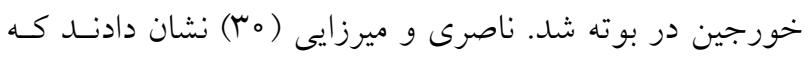

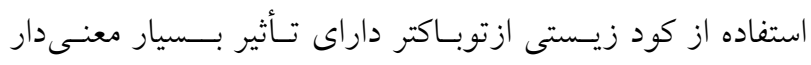

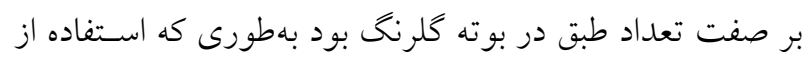

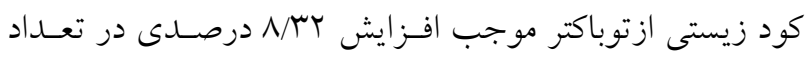

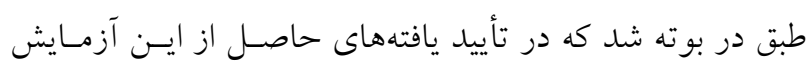

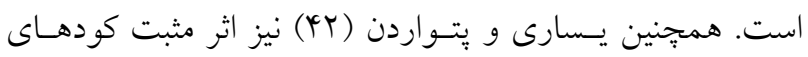

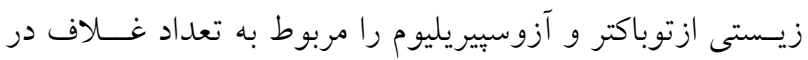

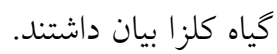

\section{تعداد دانه در خورجين}

تعداد دانه در خورجين در سطح احتمال يك درصد تحت تـأثير كود شيميايى همجنين برهم كنش كود شسيميايى و زيستى قـر درار

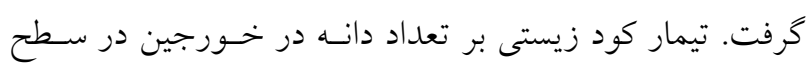

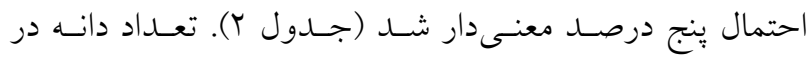

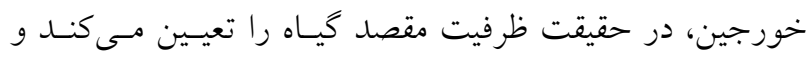

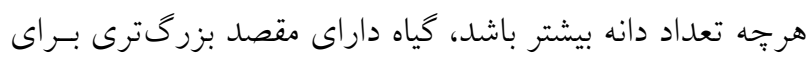

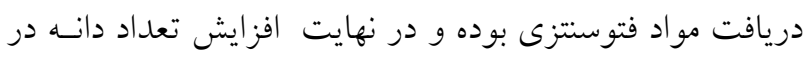

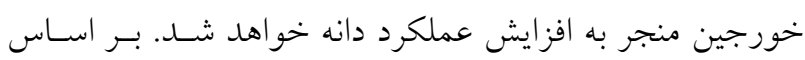

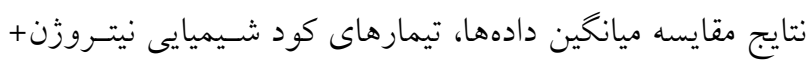

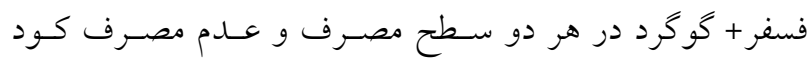

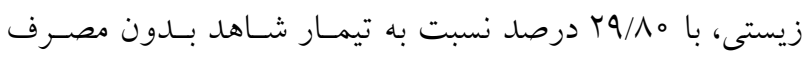

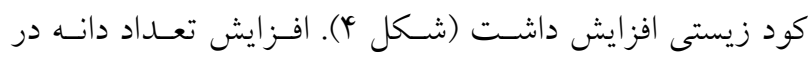
خورجين با كاربرد كودهاى زيستى مسى توانـــ بـهدليـل افـزايش جذب مواد غذايى توسط كياه باشد. از اينرو، به نظر مسىرســ

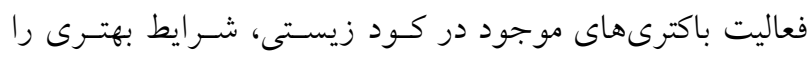

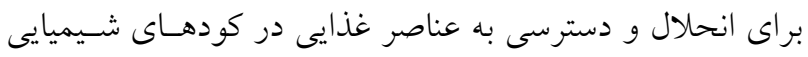

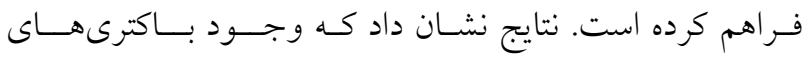

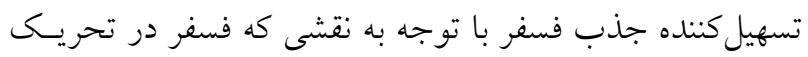

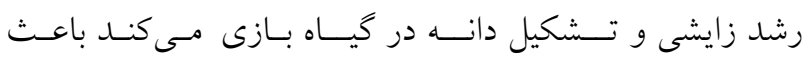




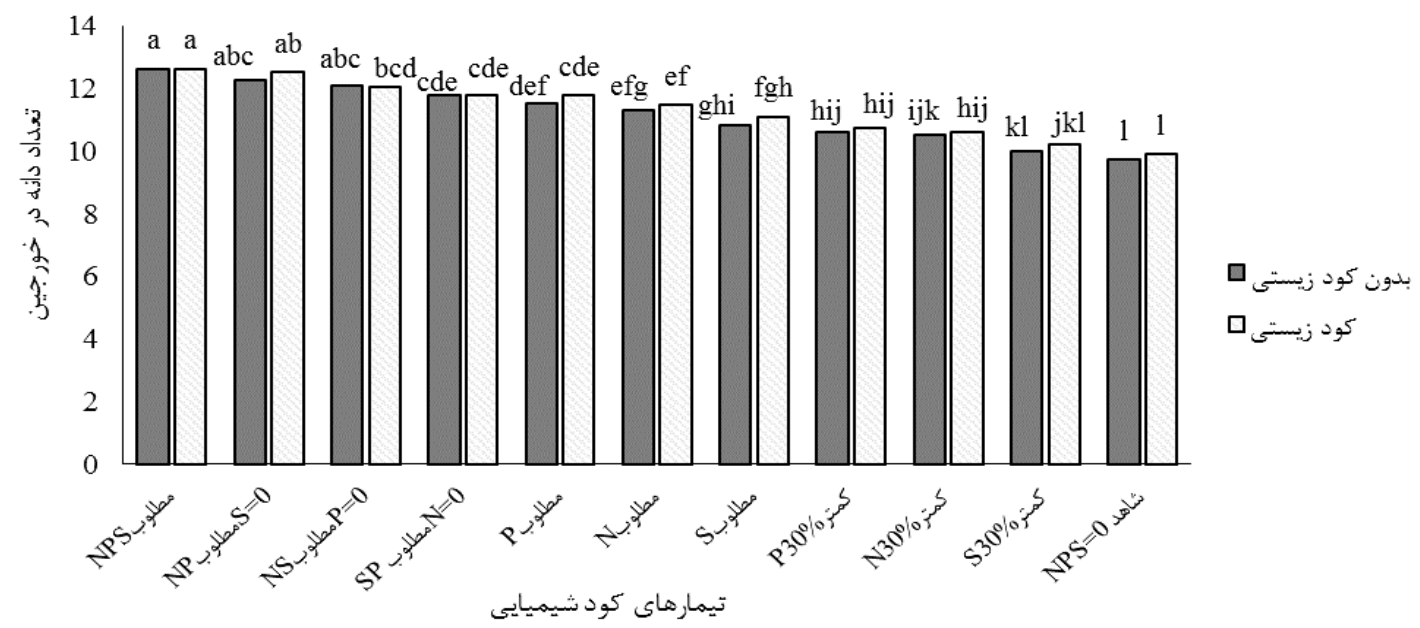

شكل f. مقايسه ميانكين اثر برهم كنش كود شيميايى در كود زيستى بر تعداد دانه در خورجين كاملينا. ستونهايى كه داراى حروف مشترى

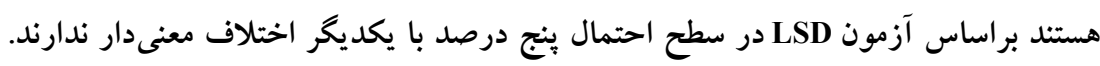

جدول r. درجه آزادى و ميانخين مربعات ويزگى هاى مربوط به عملكرد گياه كاملينا

\begin{tabular}{|c|c|c|c|c|c|}
\hline \multicolumn{4}{|c|}{ ميانكين مربعات } & \multirow{2}{*}{ درجه آزادى } & \multirow{2}{*}{ منبع تغييرات } \\
\hline شاخص برداشت & عملكرد بيولوزيكى & عملكرد دانه & وزن هزار دانه & & \\
\hline $0 / T 99^{\mathrm{ns}}$ & $r \Delta Q \wedge V / \circ \circ q^{* *}$ & $\mu / r V / \Delta \Lambda^{* *}$ & $\circ / 0 \circ 9 V^{* *}$ & $r$ & 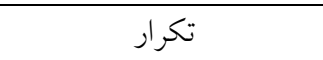 \\
\hline$|r / 90|^{* *}$ & $\mid V_{0} / M^{\mathrm{ns}}$ & $019 / \mathrm{M}^{\mathrm{ns}}$ & $0 /$ TGY** & 1 & كودزيستى \\
\hline$V / \circ Y \mu^{* * *}$ & 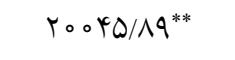 & $\mu \mid r \circ / V r^{* *}$ & $\bullet \circ \odot^{\prime} \wedge^{* *}$ & 10 & كود شيميايى \\
\hline$r Y / 9 \wedge F^{* *}$ & $1 \mu \circ 9 V / V q^{* *}$ & $\varphi \circ Я r / 4 \Lambda^{* *}$ & ०/०५ & 10 & كود زيستى × كودشيميايى \\
\hline $0 / 94 \mathrm{~V}$ & $1 \pi r r / 90$ & $199 / \pi \circ 0$ & \%००००YV & kr & ن \\
\hline$r / \circ \Lambda$ & G/N & $9 / 1 \pi$ & $0 / 40$ & - & ضريب تغييرات (٪) \\
\hline
\end{tabular}

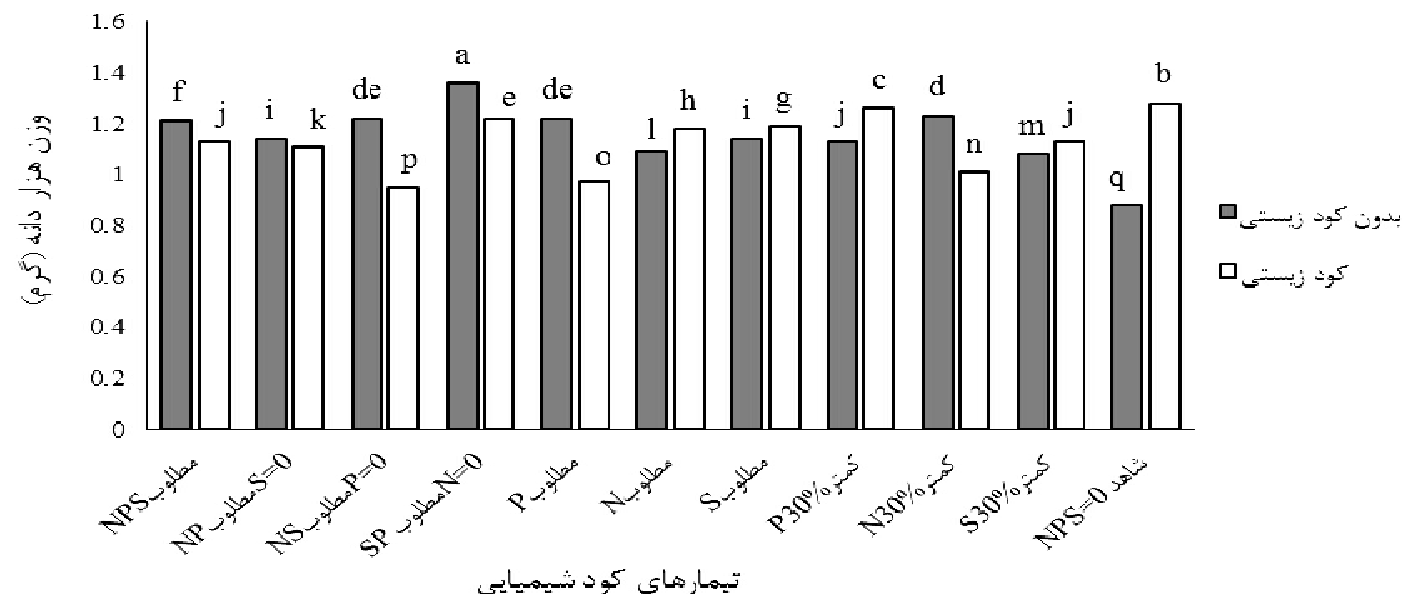

شكل ه. مقايسه ميانگين اثر برهم كنش كود شيميايى در كود زيستى بر وزن هزار دانه گياه كاملينا. ستونهايى كه داراى حروف مشترى

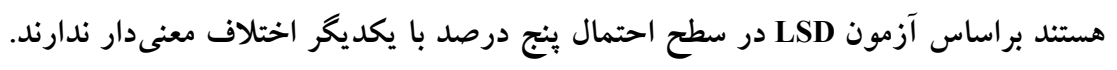




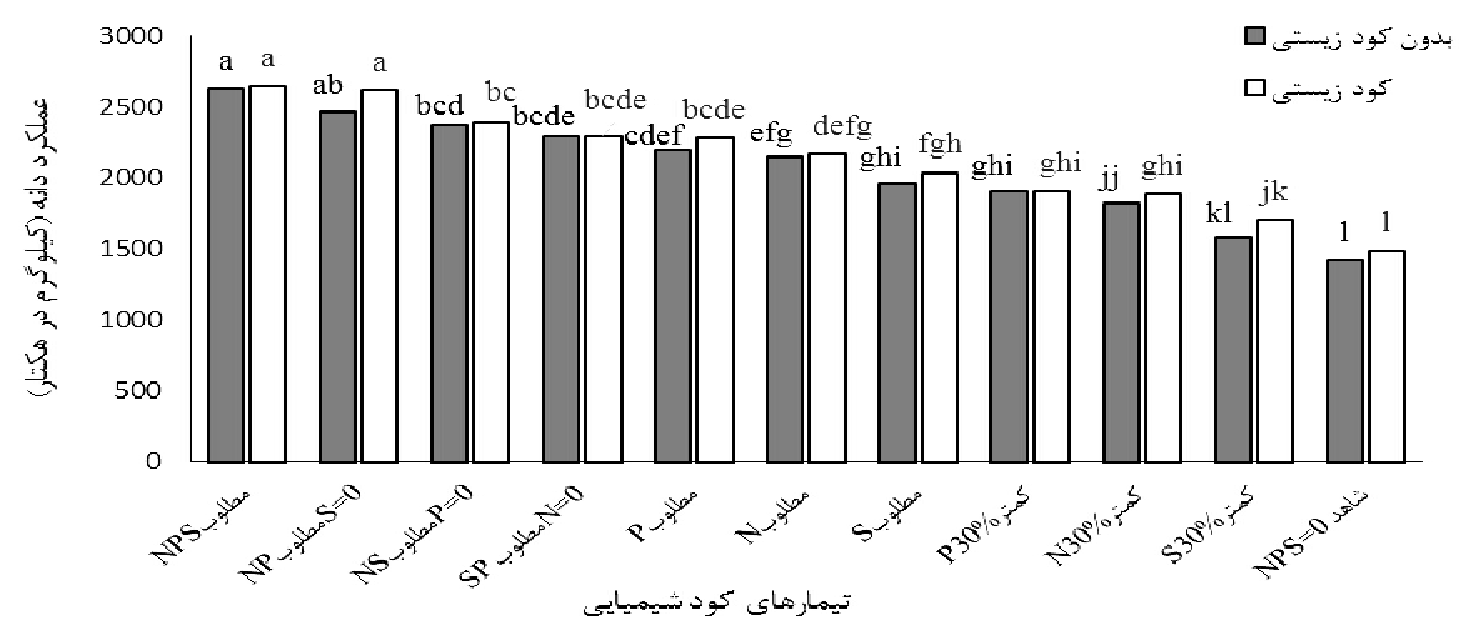

شكل و. مقايسه ميانغين اثر برهم كنش كود شيميايى در كود زيستى بر عملكرد دانه كياه كاملينا. ستونهايى كه داراى حروف مشترى هستند براساس آزمون LSD در سطح احتمال ينج درصد با يكديخر اختلاف معنى دردار ندارند.

در حضور كود شيميايى است. تيمار كود زيـستى در مقايسـه بـاـ

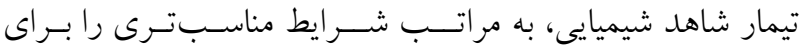

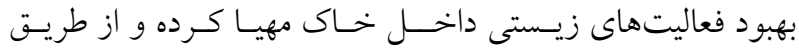
جذب مواد غـذايى توسط ريشه، موجب افزايش عملكـرد دانــهـ شده است. اين نتايج با يافتـهــاى دى و همكـاران (N) در زمينـه كاربرد كود زيستى باكتريايى مطابقت دارد. تحقيقات كايند و كوار

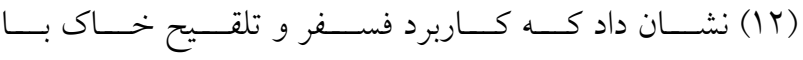

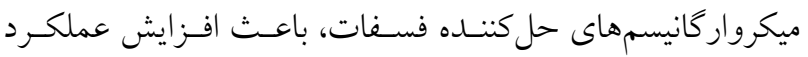

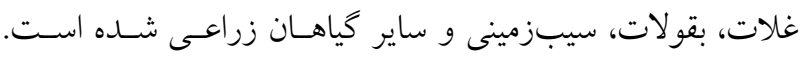

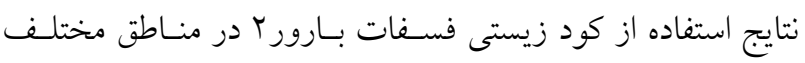

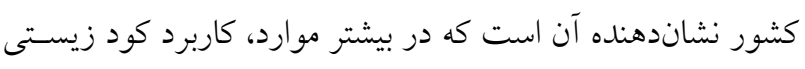

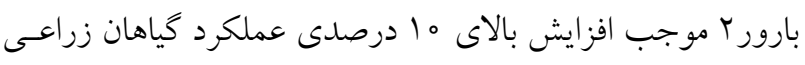
شده است (19). محسن نيا و جليليان (TV) بيان داشتند كه كـاربرد

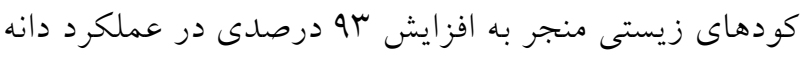

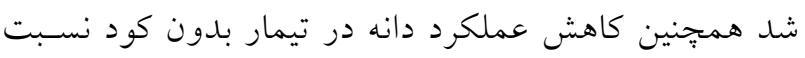

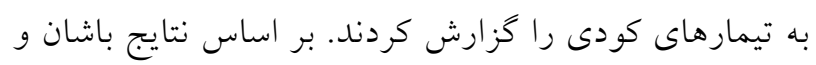

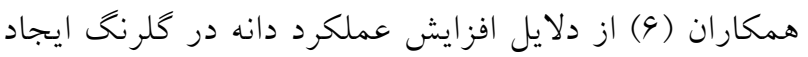
شر ايط متعادل رشد رويشى و زايشى در كيـاه و طسى شـدن

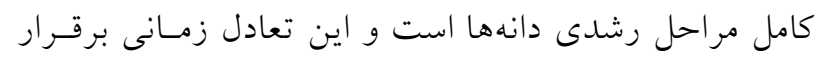
مىشود كه سطوح مختلف كود نيتروزن (براى رشد رويشى)

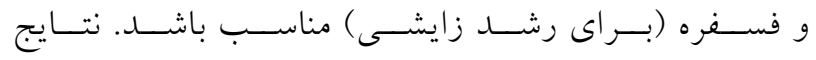

دهد و باعث عدم تكامل آنها شده و در نهايت وزن آنها كاهش

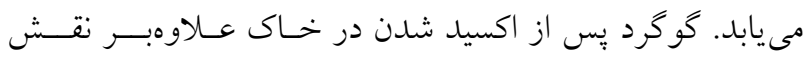

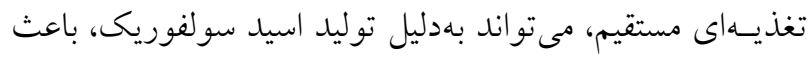
كاهش موضعى pH خاك شود و از اينرو بهطسور غيـرمستقيم

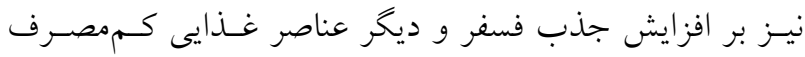

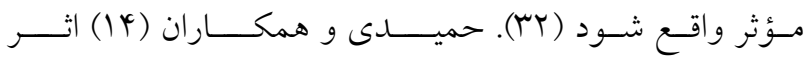

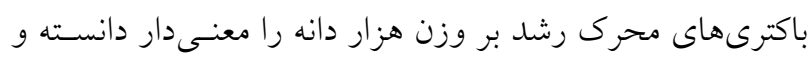

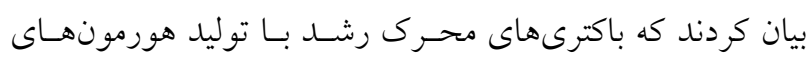

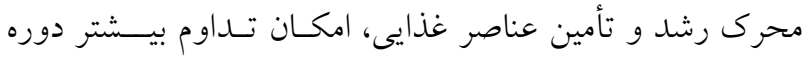

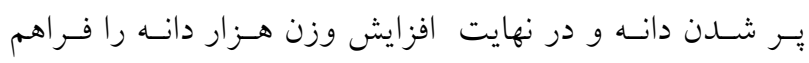

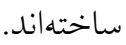

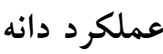

نتايج جدول تجزيه واريانس براى عملكرد دانه نشـان داد كـه اتـر كود شـيميايى و بـرهمكستش كـود شـيميايى و زيستى در سطحح احتمال يك درصد اختلاف معنى دارى وجود داشت، ولى اثر كود زيستى بر عملكرد دانه معنىدار نشد (جدول ؟). استفاده از تيمـار

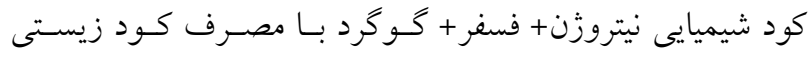
باعث افزايش ه/ م/ درصدى عملكرد دانه نسبت به تيمار شـاهد بدون مصرف كود زيستى شد (شكل 9). بهنظر مىرســ كـه ايـن

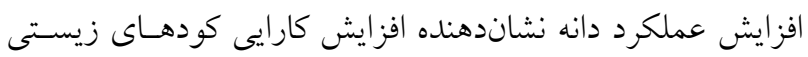




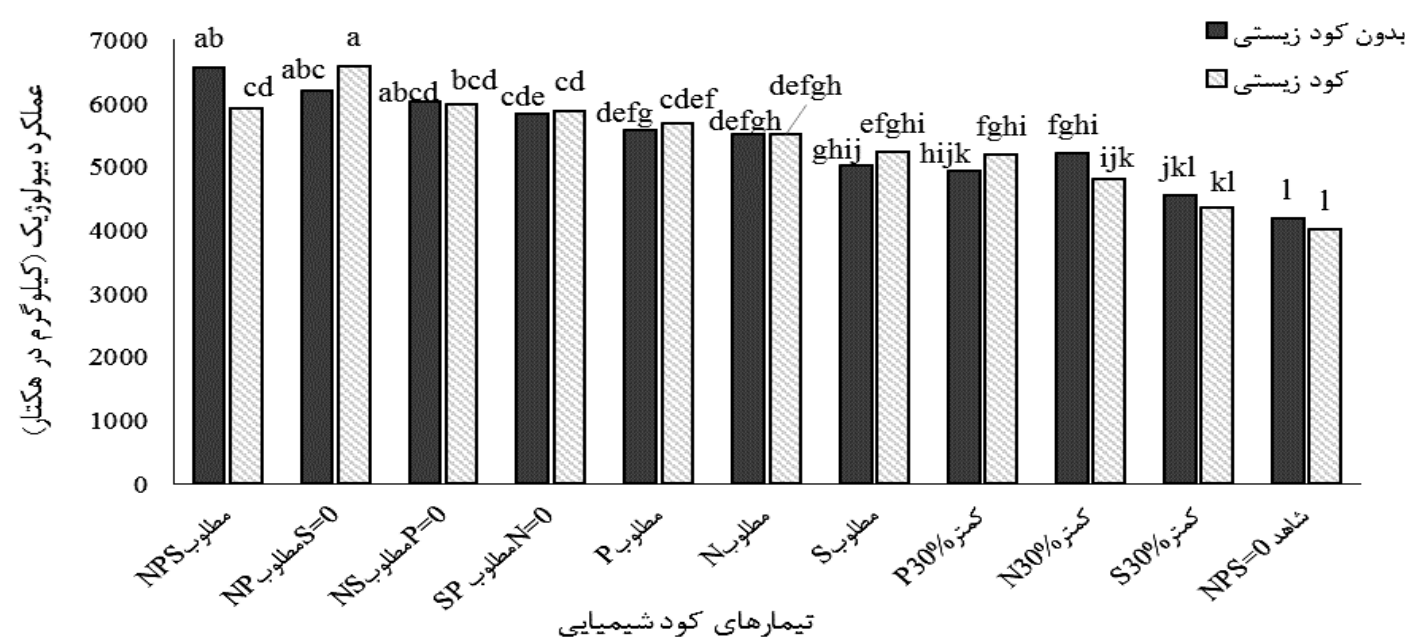

شكل V. مقايسه ميانكين اثر برهم كنش كود شيميايى در كود زيستى بر عملكرد بيولوزيك در كاملينا. ستونهايى كه داراى حروف مشترى

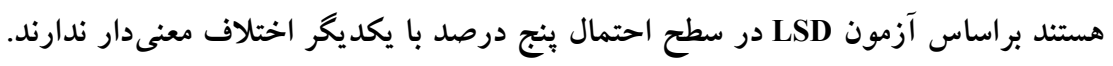

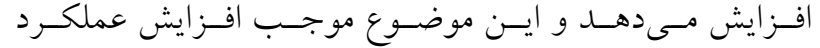

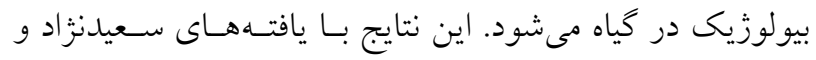
همكاران (TY) مطابقت داشت بهطورى كه استفاده از كودهـاى

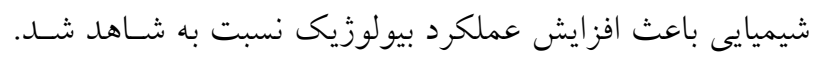
بهنظر مىرسد باكترىهاى موجـود در كـود بـا توليـد تركيبـات

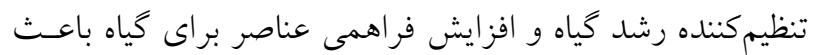

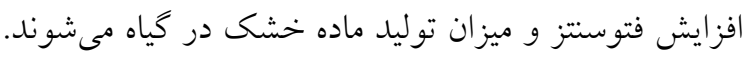
شاخص برداشت

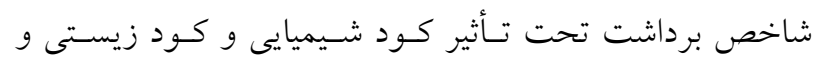

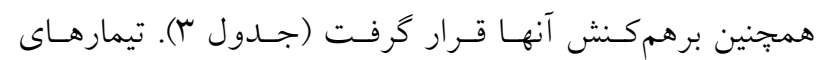
تلفيقى كود شيميايى همراه با مصرف كود زيستى بيشترين تـأثير بر تسهيم ماده خشك نسبت به شاهد داشتهاند. بر اساس مقايسه

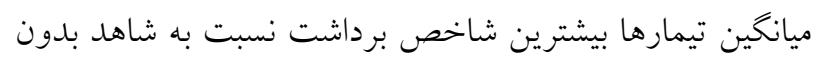

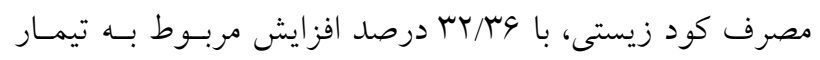

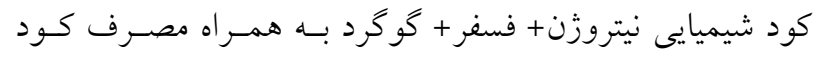
زيستى است (شكل ^). ايجـاد تعـادل در عناصـر غـذايى كيــاه مى تواند ضمن افزايش رشد رويشى در رشد زايشسى نيـز مـؤثر

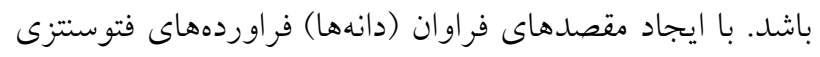
توليدى حاصل از رشد رويشى، به موقع به دانهها انتقال يافتسه و
بررسى مرادى و همكاران (Y9) نشـان داد كـهـ بـا روش تلقـيح

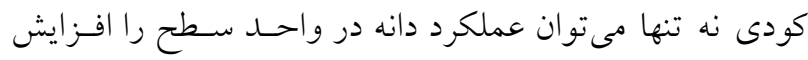

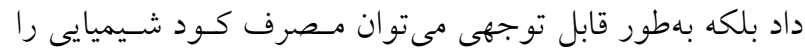

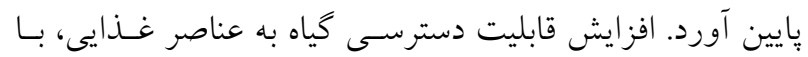
كاربرد كودهـاى شسيميايى و جذب بيشتر آنها توسط كيـاه، در

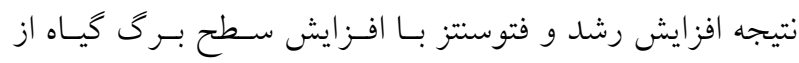
عوامـل افـزايش عملكرد دانه در تيمارهاى تلفيقسى است.

عملكرد بيولوزيك

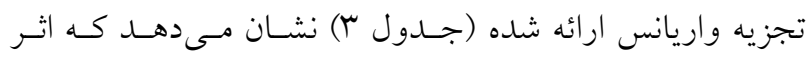

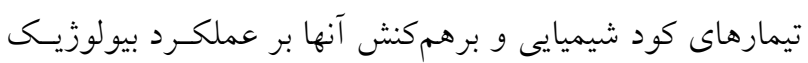

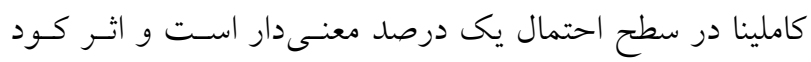

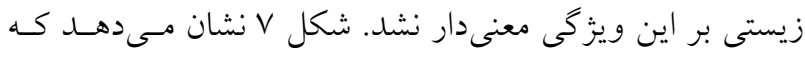

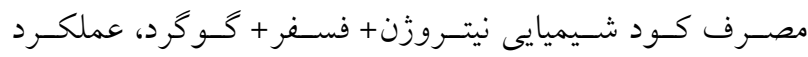

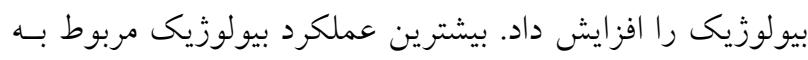

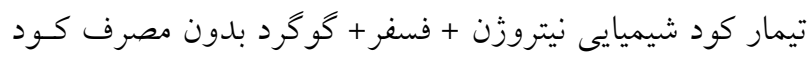
زيستى، بهميزان \$ \$ درصد افزايش نسبت به تيمار شـاهد بـاـا مصرف كود زيستى بود. جذب عناصر غذايى بيشتر توسط گياه، همجنين استفاده از سطوح كودى مختلف را سبب افزايش مـاده

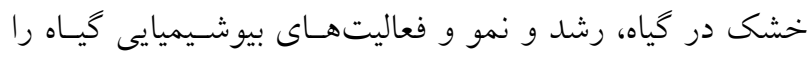




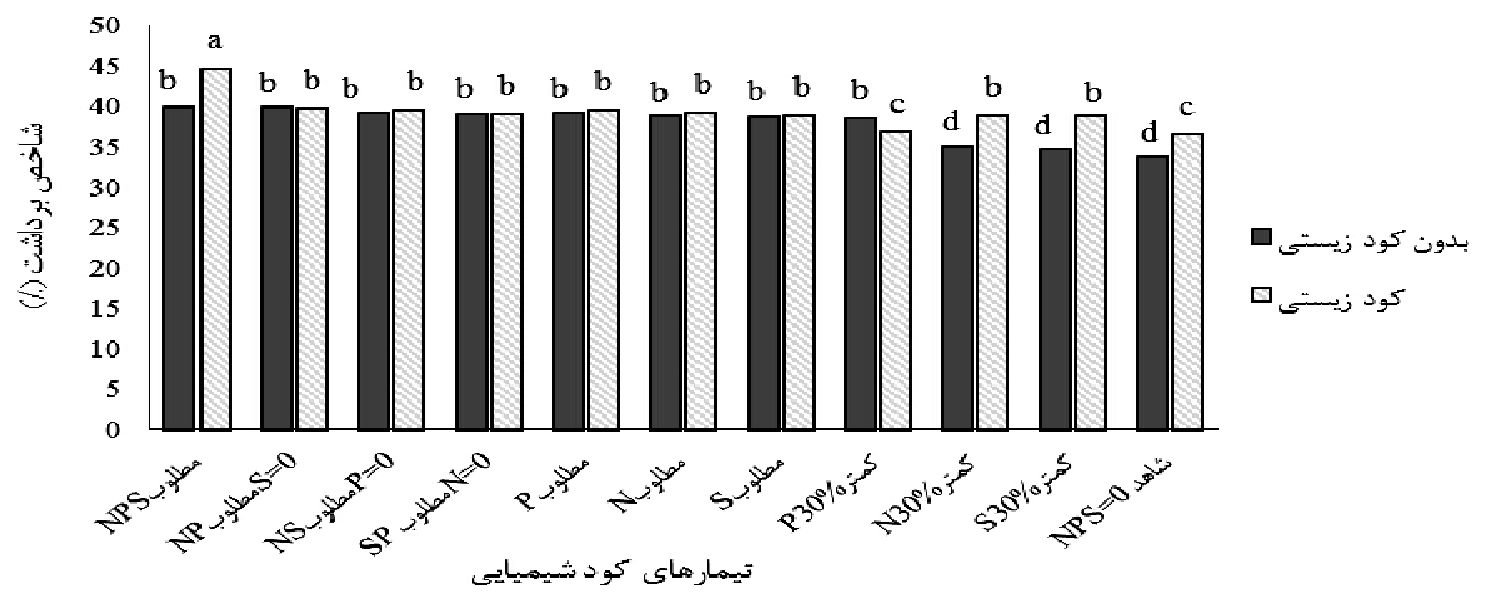

شكل ^ـ مقايسه ميانگين اثر برهم كنش كود شيميايى در كود زيستى بر شاخص برداشت در كاملينا. ستوذهايى كه داراى حروف مشترى

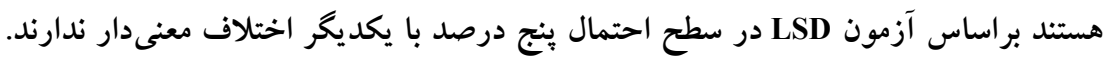

شاهد بهميزان / ا9 ادرصد نسـبت بـه تيمـار اوره كـاهش داشـت.

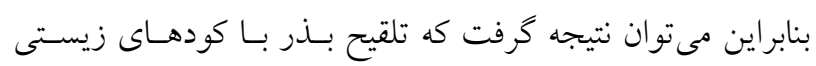

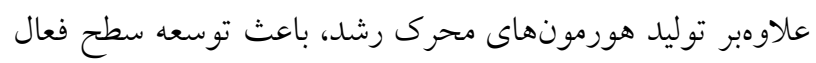

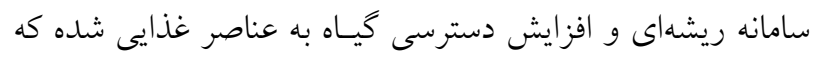

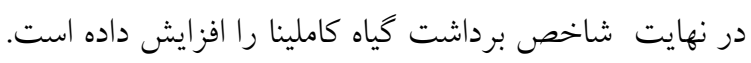

\section{نتيجه گيرى}

نتايج حاصل از اين يزوهش، نشان داد كه كـاربرد تلفيقى كودهـاى

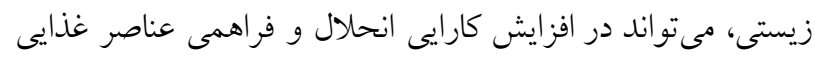

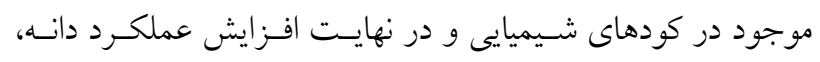

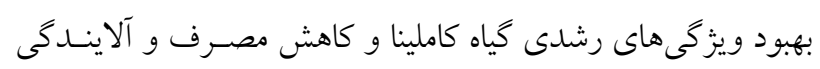

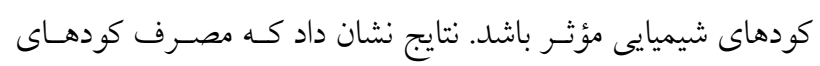

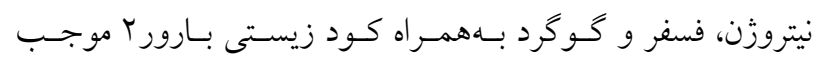

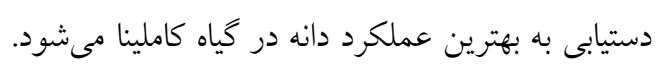

در نهايت شاخص برداشت بالا مىرود. ايسن نتسايج بـا يافتههـاى

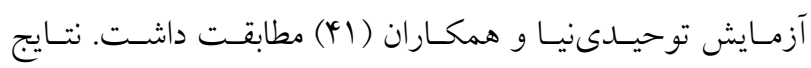

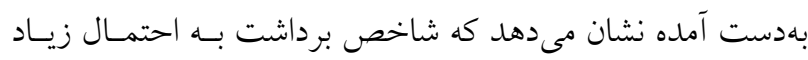
تحت تأثير شرايط محيطى و مديريتى اجراى آزمايش قرار كرفتـهـ

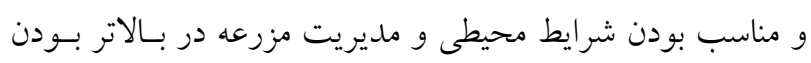

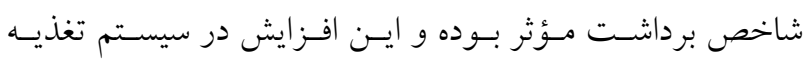

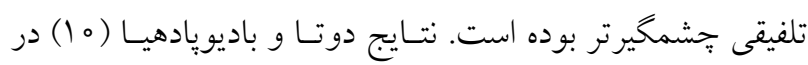

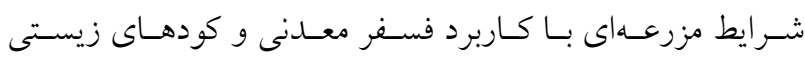

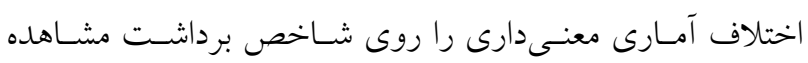

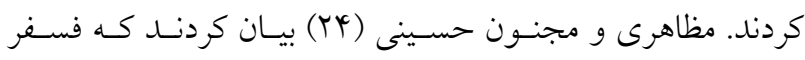

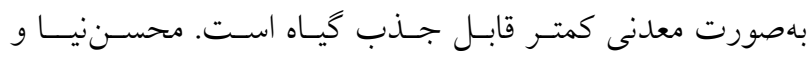

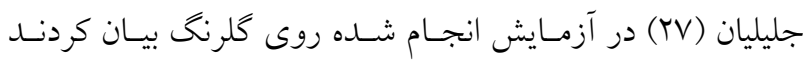

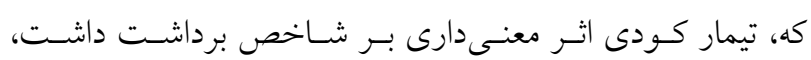

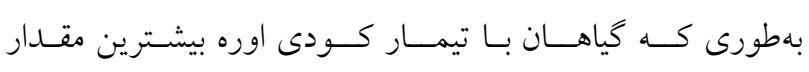
شاخص برداشت را داشتند و كمترين شاخص برداشت در تيمـار

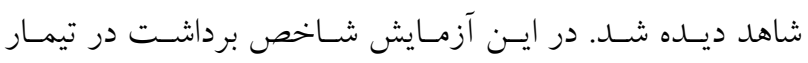

\section{منابع مورد استفاده}

1. Adesemoye, A. O., H. A. Torbert and J. W. Kloepper. 2010. Increased plant uptake of nitrogen from $15 \mathrm{~N}$-depleted fertilizer using plant growth-promoting rhizobacteria. Applied Soil Ecology 46: 54-58.

2. Ahmadi-Fard, M., K. Azizi, A. Ismaili, S. Heydari and A. Daraei Mofard. 2011. The effects of different fertilization method's on seed yield and components of lentil (Lens culinaris) under Khoramabad climatic condition, Iran. 
Journal of Agricultural Science 4 (40): 1-14. (In Farsi).

3. Altaf, A., V. Khan and M. Z. Abdin. 2000. Effect of sulfur fertilization on oil accumulation, acetyl-CoA concentration, and acetyl-CoA carboxylase activity in the developing seeds of rapeseed (Brassica campestris L.). Australian Journal of Agricultural Research 51: 1023-1029.

4. Amujoyegbe, B. J., J. T. Opbode and A. Olayinka. 2007. Effect of organic and inorganic fertilizer on yield and chlorophyll content of maize (Zea mays L.) and sorghum (Sorghum bicolour L.) moench. African Journal of Biotechnology 6(16): 1869-1873.

5. Anandham, R. and R. Sridar. 2004. Use of Sulfur Bacteria for Increased Yield and Oil Content of Groundnut. pp: 365-371. In: Kannaiyan, S., K. Kumar and K. Govindarajan (Eds.). Jodhpour, Scientific Publishers. Biofertilizers Technology, India .

6. Bashan, Y., L. Alcaraz and G. Toledo. 1992. Responses of soybean and cowpea root membranes to inoculation with Azospirillum brasilense. Symbiosis-Rehovot 13: 217-228.

7. Chen, J. 2006. The combined use of chemical and organic fertilizers and/or biofertilizer for crop growth and soil fertility. In: Proceeding of the International Workshop on Sustained Management of the Soil-Rhizosphere System for Efficient Crop Production and Fertilizer Use. Land Development Department Bangkok, Thailand. pp 16-20.

8. Dey, R., K. K. Pal, D. M. Bhatt and S. M. Chauhan. 2004. Growth promotion and yield enhancement of peanut (Arachis hypogaea L.) by application of plant growth-promoting rhizobacteria. Microbiological Research 159: 371-394.

9. Diepen Brock, W. 2000. Yield analysis of winter oilseed rape (Brassica napus L.): A review. Field Crops Research Journal 67 (1): 35-49.

10. Dutta, D. and P. Bandyopadhyay. 2009. Performance of chickpea (Cicer arietinum L.) to application of phosphorus and bio-fertilizer in laterite soil. Archives of Agronomy and Soil Science 55(2): 147-155.

11. El-Habbasha, S. F. M., S. Abd- El- Salam and M. O. Kabesh. 2007. Response of two sesame varieties (Sesamum indicum L.) to partial replacement of chemical fertilizers by bio-organic fertilizers. Research Journal of Agriculture and Biological Sciences 3(6): 563-571.

12. Gaind, S. and A. C. Gaur. 1991. Thermo tolerant phosphate solubilizing microorganisms and their interaction with mung bean. Plant and Soil 133(1): 141-149.

13. Ghasemi, S., K. Siavoshi, R. Choukan and K. Khavazi. 2011. Effect of biofertilizer phosphate on grain yield and its components of maize (Zea mays L.) cv. KSC704 under water deficit stress conditions. Seed and Plant Production Journal 27-2 (2): 219-233. (In Farsi).

14. Hamidi, A., A. Ghalavand, M. Dehghan Shoor, M. J. Malakuti, A. Asgharzadeh and R. Chakan. 2006. The effects of application of plant growth promoting rhizobacteria (PGPR) on the yield of fodder maize (Zea mays L.). Pajouhesh and Sazandegi Journal 70: 16-22. (In Farsi).

15. Han, H., K. Supanjani and D. Lee. 2006. Effect of co-inoculation with phosphate and potassium solubilizing bacteria on mineral uptake and growth of pepper and cucumber. Plant Soil and Environment 52(3): 130-136.

16. Hang, A. N. and G. Gilliard. 1991. Water requirement for winter rapeseed in central Washington. In: Proceedings of the Eighth International Rapeseed Congress, Saskatoon, Canada. Organizing Committee, Saskatoon. pp: 1235-1240.

17. Hassan zadeh, E., D. Mazaheri, M. R. Chaichi and K. Khavazi. 2006. Efficiency of phosphorus solubilizing bacteria and phosphorus chemical fertilizer on yield and yield components of barley cultivar (Karoon Dar kavir). Iranian Journal Pazhouhesh and Ssazandegi 20 (4): 111-118. (In Farsi).

18. Hopkins, W.G. 2004. Introduction to plant physiology (No. Ed. 2). John Whirly and Sons. New York.

19. Hossein Zadeh, H. 2005. Barvar Phosphate Biofertilizer Effects on Products Yield .P 45. In: Jahad University Press. Tehran. (In Farsi).

20. Kachhave, K. G., S. D. Gawand and O. D. Kohire. 1997. Uptake of nutrients by chickpea, Journal of the Indian Society of Soil Science 45: 590-591.

21. Khajehpour, M. 2004. Industrial Plants. P 563. Publishing Center of Isfahan University. (In Farsi).

22. Koochaki. A., A. Nakhtoroosh. H. Zarifketabi. 1997. In: Organic Agriculture, Ferdowsi University Press, Mashhad. (In Farsi).

23. Kumar, S., P. Pandey and D. K. Maheshwari. 2009. Reduction in dose of chemical fertilizers and growth enhancement of sesame (Sesamum indicum L.) with application of rhizospheric competent Pseudomonas aeruginosa LES4. European Journal of Soil Biology 45(4): 334-340.

24. Mazaheri, D. and N. Majnon-hossieni. 2006. Bases of General Crop Production. P 320. Tehran University of Publications. (In Farsi).

25. McVay, K. A. and Q. A. Khan. 2011. Camelina yield response to different plant populations under dryland conditions. Agronomy Journal 103 (4): 1265-1269.

26. Miller, R. M. and J. D. Jastrow. 1992. The role of mycorrhizal fungi in soil conservation1. pp. 29-44, In: Bet hlenfalvay, G. J. and R. G. Linderman (Eds.), Mycorrhizae in Sustainable Agriculture. ASA Special Publication No. 54, American Society of Agronomy, Crop Science Society of America, and Soil Science Society of America, 
Madison. Wisconsin.

27. Mohsen Nia, A. and C. Jalilian. 2012. Drought stress and fertilizer sources effects on yield of Safflower (Carthamus tinctorius L.). Journal of Agroecology 4(8): 235-245. (In Farsi).

28. Moradi, M., H. Madani and R. Cowboy Kvmami. 2010. Application of phosphorous biofertilizer and its Comparison with Chemical Phosphorus on Quantitative properties of Sunflower (Helianthus annuus L.) in Arak Region. In: Eleventh Iranian Congress of Agronomy and Plant Breeding. Tehran. (In Farsi).

29. Moradi, M., S. A. Siyadat, k. Khavazi, R. Nasseri, A. Maleki and A. Mirzaei. 2011. Biological and chemical phosphorus effects on the quantity and quality traits of spring wheat (Triticum aestivum L.). Journal of Ecophysiology of Crops and Weeds 5(18): 51-66. (In Farsi).

30. Naseri, R. and A. Mirzaei. 2010. Response of yield and yield components of Safflower (Carthamus tinctorius L.) to seed inoculation with Azotobacter and Azospirillum and different nitrogen levels under dry land condition. American-Eurasian Journal of Agricultural and Environmental Sciences 9 (4): 445-449.

31. Obour, K. A., Y. H. Sintim, E. Obeng and D. V. Jeliazkov .2015. Oilseed camelina (Camelina sativa L. Crantz): Production systems, prospects and challenges in the USA great plains. Advances in Plants and Agriculture Research 2(2): 1-10.

32. Rashidi, N. and N. K. Karimian. 1999. Sulfur and zinc effects on growth and chemical composition of maize (Zea mays L.) in calcareous soil. In: Proceeding of the $6^{\text {th }}$ Iranian Soil Science Congress, Mashhad. (In Farsi).

33. Rodriguez, H. and R. Fraga. 1999. Phosphate solubilizing bacteria and their role in plant growth promotion. Biotechnology Advances 17(4-5): 319-339.

34. Saeednejad, A. H., H. R. Khazaei and P. Rezvani Moghadam. 2012. Organic biological and chemical fertilizer effects on some morphological traits, yield and yield components of sorghum (Sorghum bicolor L.). Iranian Journal of Field Crops Research 10(3): 503-510. (In Farsi).

35. Salardini, A. 1995. Soil Fertility. Tehran University of Publications. (In Farsi).

36. Salmanzadeh, S., H. Abbas Dokht, A. Gholami, M. Gholipour and F. H. Asghari. 2012. Barvar 2 Rhizobium japonicum bacteria biofertilizer and priming effectss on yield of soybean (Glycine max L.). In: Proceeding of the Twelfth Iranian Congress of Agronomy and Plant Breeding. Islamic Azad University of Karaj Branch. (In Farsi).

37. Sana, M. A., M. Ali, M. Asghar Malik, M. Farrukh Saleem and M. Rafiq. 2003. Comparative yield potential and oil contents of different canola cultivars (Brassica napus L.). Pakistan Journal of Agronomy 2 (1): 1-7.

38. Selosse, M. A., E. Baudoin and P. Vandenkoornhyse. 2004. Symbiotic microorganisms, a key for ecological success and protection of plants. Comptes Rendus Biologies 327(7): 639-648.

39. Shaalan, M. N. 2005. Influence of biofertilizers and chicken manure on growth, yield and seeds quality of (Nigella sativa L.) plants. Egyptian Journal of Agricultural Research 83 (2): 811-828.

40. Son, T. T. N., C. N. Diep and T. T. M. Giang. 2006. Effect of Bradyrhizobia and phosphate solubilizing bacteria application on soybean (Glycine max L.) in rotational system in the Mekong delta. Omonrice 14: 48-57.

41. Tohidinia, M. A., D. Mazaheri, S. M. Bagher-Hosseini and H. Madani. 2014. Barvar-2 and chemical phosphorus fertilizer effects on maize (Zea mays cv. SC704) seed yield and yield components. Iranian Journal of Crop Sciences 15(4): 295-307. (In Farsi).

42. Yasari, E. and A. M. Patwardhan. 2007. Effects of (Aztobacter and Azospirillium) inoculations and chemical fertilizers on growth and productivity of canola (Brassica napus L.). Asian Journal of Plant Sciences 6 (1): $77-82$.

43. Zubr, J. 1997. Oil-seed crop: Camelina sativa. Industrial Crops and Products 6(2): 113-119. 


\title{
Evaluation of Some Growth and Yield Traits of Camelina sativa L. under the Influence of Biological and Chemical Fertilizers
}

\author{
M. Hasani Balyani ${ }^{1}$, M. R. Tadayon ${ }^{2}$ and A. A. Fadaei Tehrani ${ }^{3}$
}

(Received: June 2-2018; Accepted: June 1-2019)

\begin{abstract}
In order to study the effect of phosphate biofertilizer and chemical fertilizers of nitrogen, phosphorus and sulfur on some growth and yield components of Camelina sativa L., a study was conducted based on a factorial experiment; this was done in a randomized complete block design with three replications at Kazeroon during the 2016 growing season. Treatments included bio-based phosphorus (P) fertilizers (Barvar-2) containing phosphate solubilizing bacteria (PSB) (the Pseudomonas putida Strain 13P and Strain 5P and the Pantoea agglomerans Strain 5P) as the first factor at two levels (inoculated and uninoculated seeds) and chemical fertilizer as the second factor, including control, nitrogen, phosphorus and sulfur alone, based on the recommended doses of NPS and 50\% recommended NPS fertilizers. The results showed that the effect of the use of the biofertilizer on plant height and number of seeds per silique and the number of siliques per plant, 1000 seed weight and harvest index were significant, but the number of branches, grain yield and biological yield were not significant. The use of chemical fertilizer as well as the interaction of chemical fertilizers $\times$ phosphate biofertilizer on all traits was significant. The combined use of bio-inoculants and chemical nitrogen + phosphorus + sulfur fertilizer, as compared to the control, increased plant height by $50.58 \%$, the number of branches by $26.7 \%$, seed number per silique by $29.8 \%$, the grain yield by $86.88 \%$, biologic yield by $63.58 \%$, and harvest index by $32.36 \%$. Nitrogen consumption increased the number of siliques per plant by $27.84 \%$ and nitrogen + sulfur treatment imrpoved 1000 seed weight by $54.54 \%$, relative to the control treatment. So, according to the results of this experiment; the best fertilizer treatment for Camelina sativa L. production was the combination of nitrogen + phosphorus + sulfur fertilizer plus biofertilizer application.
\end{abstract}

Keywords: 1000 seed weight, Biologic yield, Harvest index, Number of silique, Seed number

\footnotetext{
1, 2. MSc. Student and Associate Professor, Respectively, Department of Agronomy, Faculty Agriculture, Shahrekord University, Shahrekord, Iran.

3: Associate Professor, Department of Plant Protection, Faculty Agriculture, Shahrekord University, Shahrekord University, Shahrekord, Iran.

*: Corresponding Author, Email: mrtadayon@yahoo.com
} 